\title{
DIVERSIFICATION: IMPACT OF MONOPOLY POLICY UPON MULTI-PRODUCT FIRMS
}

\author{
G. E. HALE $\dagger$
}

Production or distribution of more than one commodity, commonly called diversification, is a widespread phenomenon in modern industry. Degrees of diversification vary widely. A manufacturer may produce two sizes of the same screw-driver; ${ }^{1}$ another may offer photographic film in both color and black-and-white. ${ }^{2}$ Some firms spread across an entire industry; ${ }^{3}$ others lap over into adjacent fields. ${ }^{4}$ In some instances the commodities produced are wholly dissimilar: a prominent company has two subsidiaries, one building railway cars and the other erecting oil refineries. ${ }^{5}$ Investment trusts carry diversification farther. While some focus upon a specific industry ${ }^{\circ}$ and others

$\doteqdot$ A.B. Yale 1935, L.L.B. Harvard 1938, J.S.D. University of Chicago 1940, member of the Illinois and federal bars. Assisted by Rosemary D. Hale, A.B. 1940, Mount Holyoke, M.A. 1946, American University, instructor in economics, Lake Forest College. Special acknowledgment for acute suggestions is due Professor William L. Cary, School of Law, Northwestern University. The authors are also under obligations to Messrs. Melville C. Williams, W. S. Bodman and J. W. Close of the Chicago bar. Mr. Ernest S. Ballard kindly made available his copies of the briefs and record in the General Motors case. For factual data the authors are grateful to Messrs. Stuart S. Palmer, M. P. Stark, David W. Dangler, U. B. Grannis and Mrs. R. G. Anderson.

1. Conant, One or Many Lines? Barron's, July 8, 1940, p. 7.

2. Richmond, Profits Out of Pictures, Magazine of Wall Street, Oct. 23, 1937, p. 27. A tobacco company makes six brands of cigarettes, nine brands of smoking tobacco and nine brands of chewing tobacco. Liggetr \& Myers Tobacco Company, ANN. REP. FOR 1948 at 12 . A prominent insurance company does two principal lines of business. Under the heading of "bonding business" it lists fidelity bonds, bankers" bonds, fiduciary bonds, public official bonds, court bonds, forgery bonds and contract bonds. Under the heading of "casualty insurance" it lists workmen's compensation, automobile liability, automobile theft, general liability, burglary, accident and health, boiler and machinery, glass and water damage. Maryland Casualty Company, ANN. REP. FOR 1948 at 19.

3. A rubber manufacturer produced tires and tubes, footwear, raincoats, hose, belting, motor mountings, foam latex rubber, baby pants, gloves and toys. U.S. Rubber's Tro-Way Stretch, Bus. Week, Dec. 11, 1948, p. 83. (Subsequently the same firm diversified into the production of plastics, lastex yarn, radiant heating panels, textiles, laundry starch and chemicals. Id. at 84.)

4. A 32-page booklet entitled Products and Processes was enclosed with 1948 Ann. Rep., Union Carbine and Chemical Corp. It listed the products of the company in five general groups as follows: (1) alloys and metals, (2) chemicals, (3) electrodes, carbons and batteries, (4) industrial gases and carbide and (5) plastics. The products themselves were too numerous to count: E. I. DuPont deNemours \& Company operates through ten departments plus a Mexican subsidiary, four controlled companies and four subsidiaries engaged in foreign trade. Each manufacturing department has a long list of products. E. I. DuPONT DENEMrours \& Co., ANN. REP., 1948 , at 48 et seq. In addition thereto, it owns $10,000,000$ shares of the common stock of General Motors Corporation, constituting $22.7 \%$ of the outstanding common stock. Id. at 19. Cf. AMrerican Home Propucts Corp., ANN. Rep., 1948, at 23 et seq.; General Electric Co., Ann. Rep., 1948, at 23 et seq.; General Motors, Fortune, Dec. 1938, D. 41, 44 et seq., 170 et sea.

5. Prrltman, Inc., AnN. Rep., 1948, at 7 et seq.

6. Chemical Fund, Inc., Ann. ReP., 1948, at 4, 6, 13. Insurance companies are similar to investment trusts. MARYLAND CaSUalty Co., ANN. REP., 1948, at 10 et seq. 
provide management for any type of enterprise, ${ }^{7}$ the majority are intentionally "diversified" over the whole field of commerce. This article examines the relationship between diversification and the problem of monopoly.

Multi-product firms are one of several types giving rise to monopoly problems. Vertical integration, the combination of successive stages of production or distribution in a single concern, is another. ${ }^{8}$ The term "horizontal integration" usually refers to a union of former competitors making the same product. Diversification is sometimes called "distribution" or "circuitous" 9 or "conglomerate" or "lateral" 10 integration. Its existence in trade is roughly as common as vertical integration. ${ }^{\text {II }}$ But to date its bearing upon monopoly has received less attention.

\section{A PAGE OF History}

Diversification is a recent phenomenon. Early corporate charters were granted for narrow purposes, and in the eighteenth century companies seem to have had only one general mission. Thus a concern was organized as an insurance company, a bank, a toll bridge company or a turnpike company. ${ }^{12}$ A few firms were granted authority to undertake different objects, but usually in such obvious combinations as operating both a bridge and a toll road or both a bridge and a canal. ${ }^{13}$ In general, legislatures were chary of granting, and the companies hesitant to ask, combinations of diverse powers. ${ }^{14}$

Because the system of special acts had led to abuses and scandals, in the latter part of the nineteenth century many states turned away from the practice of granting special charters to corporations. The first to do so was New Jersey, which amended its constitution in 1875 to forbid the further granting of such privileges. ${ }^{15}$ Other states quickly

7. Happy AGWI, Fortune, Feb. 1949, p. 16; Financial Fun after Fifty, Modern Industry, April 15, 1948, p. 67 .

8. Hale, Vertical Integration, 49 Cot. L. Rev. 921 (1949). Cf. Canadian Pacific Railway, Fortune, Sept. 1930, pp. 42, 144. (Railroad's investments in hotels, coal mining ventures, etc.. made chiefly to create traffic.)

9. Hale, Trust Dissolution, 40 CoL. L. Rev. 615, 626 (1940),

10. Buchanan, The Economics of Corporate Enterprise 309 (1940).

11. Thorp and Crowder, THE StruCture of Industry 168 (T.N.E.C. Monograph \#27, 76th Cong., 3rd Sess. 1941). Unfortunately the census data from which the foregoing conclusions were reached is not sufficiently precise to permit fine distinctions between the various types of integration. Id. at 597 .

12. 2 Davis, Essays in the Earlier History of Amierican Corporations 22 et seq. (1917). A railroad chartered to operate from $X$ to $Y$ cannot divert its capital from the objects contemplated and extend its lines to $Z$. Pearce v. Madison \& Indianapolis Railroad, 62 U.S. 441, 443 (1858); cf. Banet v. Alton Railroad, 13 IIl. 504 (1851).

13. 2 DAvis, op. cit. supra note 12 , at 318 .

14. Id. at 319. Cf. Ramsey v. Tod, 95 Tex. 614,69 S.W. 133 (1902); Williams v. Citizens' Enterprise Co., 25 Ind. App. 351, 57 N.E. 581 (1900). But cf. Marion Bond Co. v. Mexican Coffee Co., 160 Ind. 558, 65 N.E. 748 (1902).

15. Davis, op. cit. supra note 12, at 205. 
followed. The reaction against abuses incidental to special charters, joined with the feeling that there should be full equality of opportunity to incorporate, encouraged the adoption of general incorporation acts. ${ }^{16}$ Today almost every state grants corporate charters under general statutes whereby the issuance of the authority becomes a ministerial act. ${ }^{17}$ It follows that the persons forming a corporation may choose the powers it shall enjoy. As a consequence, corporate charters now generally contain broadly diversified authority. ${ }^{18}$

About the same time several allied developments helped clear the way for diversified enterprise. New legislation made amendment of corporate charters far easier. Common law and statutory rules requiring unanimous consent of shareholders were abrogated. ${ }^{19}$ Today it is the general practice to permit broad amendments with few formalities. ${ }^{20}$

Relaxation of the formerly rigorous doctrine of ultra vires has had a similar effect. Until recent times the corporate charter was the strict measure of a company's powers. Any action beyond its confines was unlawful ${ }^{21}$ and the corporation itself could plead its own lack of capacity in order to defeat the obligation of contracts entered into in good faith. Gross injustice was often the result. In the first third of the present century a revulsion from the doctrine ${ }^{22}$ resulted in legislative action. In most jurisdictions today only the state or the shareholders may assert that corporate acts are ultra vires. ${ }^{23}$

One further aspect of state incorporation statutes deserves mention. When one concern holds stock in another, diversification may result just as readily as in the case of a corporation empowered to em-

16. Dodd and Baker, Cases on Business Assocratrons 20 (1940). See also Rutledge, Significant Trends in Modern Incorporation Statutes, 22 WASE. U.L.Q. 305, 306 (1937).

17. Rutledge, supra note 16 , at 313 et seq.

18. $R e$ Humphrey Advertising Co., 177 Fed. 187, 188 (7th Cir. 1910).

19. Dodd, Statutory Developments in Business Corporation Law, 50 HaRv. L. Rev. 27, 33, 37 (1936).

20. See Rutledge, supra note 16 , at 324 et sea.

21. Morawetz, Private Corporations, 23 (1st ed. 1882). In People ex rel. Peabody v. Chicago Gas Trust Co., 130 Ill. 268, 283, 22 N.E. 798, 799 (1889) it was said: "Corporations may only exercise such powers as may be conferred by the legislative body creating them, either in express terms, or by necessary implication . . ." Only slight deviations were permitted under the doctrine. Brown v. Winnisimmet Co., 11 Allen 326, 333 (Mass, 1865) ; 6 Fletcher, Cyclopedia of Private CorporaTroNs $\$ 2535$ (Perm. ed. 1931).

22. Hale, A Field for Corporate Law Revision-Collateral Attack, 11 ILL. L. Rev. 1, 2 et seq. (1927). Ease of amendment had removed the substance of even the state's obligation to ultra vires acts. Carpenter, Should the Doctrine of Ultra Vires be Discarded?, 33 Yale L.J. 49, 64 (1923).

23. E.g., Illinois General Corporation Act, 1919, \$ 75. Cf. Rutledge Significant Trends in Modern Incorporation Statutes, 22 WASH. U.L.Q. 305, 310 (1937). Ultra vires was a doctrine designed primarily to protect the dissenting shareholder. BRICE, Ultra Vires 78n. (Green ed. 1880). Diversification was not regarded as dangerous to the state. Thompson, The Doctrine of Ultra Vires in Relation to Private Corporations, 28 AM. LAw REv. 376, 396 et seq. (1894); Carpenter, supra note 22, at 64. 
bark upon several different branches of endeavor. Until modern times corporations were not allowed to hold stock of other corporations. ${ }^{24}$ About the same time that special charters were replaced by articles of incorporation under general acts, the states began to permit corporations to hold stock, ${ }^{25}$ until today the law in almost every state permits it. $^{20}$ It is true that there are some limitations in the permissive statutes. For example, the former Illinois law permitted one corporation to hold stock in another so long as the acquisition did not substantially lessen competition or tend to create a monopoly. ${ }^{27}$ It was clear, however, that the limitation in question was designed to prevent horizontal integration and not diversification. Thus an express provision declared:

. . This section shall not apply to corporations purchasing . . . stock solely for investment . . . nor shall anything contained in this section prevent a corporation from causing the formation of a subsidiary corporation or from owning stock in such a corporation, for the actual carrying on of its immediate lawful business or the natural and legitimate branches or extensions thereof. . . . ${ }^{28}$

It is worth noting that section 7 of the Clayton Act, after which the quoted statute was modelled, itself permitted the formation of subsidiary corporations for the same purposes. ${ }^{29}$

Thus within the field of the "private" law of corporations--that branch of the law dealing with corporate powers and the relationship of the component parts of the association-diversification is now readily achieved. Indeed, it is unquestioned that diversified business may be conducted in corporate form.

24. See, e.g., Hall v. Woods, 325 Ill. 114, 130, 156 N.E. 258, 264 (1927). Accord: Golden v. Cervenka, 278 Ill. 409, 440, 116 N.E. 273, 286 (1917). See HALE, ThE Law of Private Corporations In Inlynois 7 (1916); Hale, Holding Companies in Illinois Law, 7 Ill. L. Rev. 529, 535 (1913); 6 Fletcher, CyclopediA of Private CoRPORATIONS \$2825 (Perm. ed. 1931).

25. Keasbey, New Jersey and the Great Corporations, 13 HARv. L. Rev. 198, 207 (1899); Rutledge, supra note 23 , at 307.

26. E.g., Roth v. Ahrensfeld, 300 Iil. App. 312, 321, 21 N.E.2d 21, 25 (1939), aff'd, 373 Iil. 550,27 N.E.2d $445^{\prime}$ (1940).

27 Illinois General Corporation Act § 7, Ir.. Rev. Stats. c. 32, §\$ 1 et seq. (1931).

28. Ibid.

29. 15 U.S.C. $\S 18$ (1946), where it is provided that nothing therein shall prevent a corporation from "causing the formation of subsidiary corporations for the actual carrying-on of their immediate lawful business, or the natural and legitimate branches or extensions thereof . "Limitations remain in selected fields. National Banking Act, 18 Stat. 123 (1874) as amended, 12 U.S.C. $\$ 24$ (1946). National banking associations are also prohibited from underwriting the issuance of securities. Ibid. Utilities often are denied the privilege of holding stock. Annotated Laws of Mass., c. $156 \$ 5$ (1948). See Steckler v. Pennroad Corp., 44 F. Supp. 800, 803 (E.D. Pa. 1942). Public Utility Holding Co. Act of 1935, 15 U.S.C. \$79i (1946). The Investment Co. Act of 1940,15 U.S.C. $\$ 80 \mathrm{a}-5$ (b) (1) (1946), defines a "diversified company" as one with no more than $5 \%$ of its assets invested in the securities of a single issuer. But, in general, the holding of stock is now condoned. BONBRIGHT AND Means, The Holding Company 64 (1932). 


\section{Assumed Legality of Diversification in Past}

Our problem is the relationship between diversification and the law of monopoly, which includes the common law of the several states, state legislation and the familiar federal antitrust acts. Although such law long ago parted company with the "private" law of corporations, monopoly policy in the past has not frowned upon diversification.

Perhaps the leading case is United States $v$. Winslow, ${ }^{30}$ the first major decision in the trio affecting the United Shoe Machinery Co. It was there proven that the defendants had combined three previously existing concerns. The first of those firms was the producer of $60 \%$ of the lasting machines used in the manufacture of shoes, while the second made $80 \%$ of the welt sewing machines and outsole stitching machines. The third produced $70 \%$ of the heeling machines and $80 \%$ of all metallic fastening machines. All the machines in question were protected by patent rights. The combined concern refused to sell machines but leased them to shoe manufacturers on condition that each lessee use all the machines produced by the combination. It was held that the defendants had not violated the Sherman Act. Mr. Justice Holmes, laying stress upon the lack of competition between the three component firms in the combination, said:

As . . . they did not compete with one another, it is hard to see why the collective business should be any worse than its component parts. It is said that from $70 \%$ to $80 \%$ of all the shoe machinery business was put into a single hand. . . . Taking it as true we can see no greater objection to one corporation manufacturing $70 \%$ of three non-competing groups of patented machines collectively used for making a single product than to those corporations making the same proportion of one group each. The disintegration aimed at by the statute does not extend to reducing all manufacture to isolated units of the lowest degree. ${ }^{31}$

In many ways the $W$ inslow case is a perfect authority for the proposition that diversification is lawful. Since each machine was protected by patents, the combination could lawfully enjoy a high percentage of the output of that particular commodity. Yet the fact that such high percentages of total production were attained for each of the several commodities makes the case a stronger authority for the proposition

30. United States v. Winslow, 195 Fed. 578 (D. Mass. 1912) aff'd 227 U. S. 202 (1913). Argument for the defendant stressed the fact that the combination did not involve previously competing firms. $C f$. United States Shoe Machinery Co. v. LaChapelle, 212 Mass. 467, 478, 99 N.E. 289, 291 (1912).

31. United States v. Winslow, 227 U.S. 202, 217 (1913). A similar result was reached in the lower court in 195 Fed. 578 (D. Mass. 1912). Accord: United States v. United Shoe Machinery Co., 247 U.S. 32 (1918). 
that diversification does not infringe the statute. Subsequently, of course, the tying clauses involved in the leases of the shoe machinery company were declared unlawful under the specific prohibitions of section 3 of the Clayton Act. ${ }^{32}$

Another important decision is Alexander Milburn \& Co. v. Union Carbide and Carbon Corp. ${ }^{33}$ That was an action for triple damages under section 7 of the Sherman Act. Plaintiff alleged that the defendants, Union Carbide and Carbon Corp. and its subsidiary corporations, constituted a combination in restraint of trade whereby the plaintiff had suffered damages. One subsidiary was a maker of calcium carbide. Another, the Prest-O-Lite Co., converted calcium carbide into acetylene gas. Oxweld Acetylene Co. produced apparatus for welding with acetylene gas. Oxweld Railroad Service Co. used the foregoing products to weld railroad equipment in various locations. It was held that the combination was not unlawful. In the course of his opinion Judge Parker said :

Of course plaintiff has shown a combination existing on the part of these defendants; but it has not shown a combination in restraint of trade. Their business . . . is not competing but complementary. . . .

As there is no competition between their products, the unity of control secured by the stock ownership of Union Carbide and Carbon Corp. cannot be said to stifle competition between the companies themselves. The combination results not in suppression of competition, but in greater efficiency on the part of the constituent companies, and although as pointed out by plaintiff, this unified control results in bringing larger resources under one management, mere size does not constitute a violation of the Act . . . nor is it violated merely by reason of the fact that there is brought under control companies engaged in non-competing branches of the industry. ${ }^{34}$

32. 38 STAT. 731 (1914), 15 U.S.C. $\$ 14$ (1946); United Shoe Machinery Corp. v. United States, 258 U.S. 451 (1922).

33. Alexander Milburn Co. v. Union Carbide \& Carbon Corp., 15 F.2d 678 (4th Cir. 1926) cert. den. 273 U.S. 757 (1927).

34. Id. at 682 et seq. As to the old trust dissolution cases, it is said in Hale, Trust Dissolution, 40 CoL. L. REv. 615, 625 (1940): "There was only a slight amount of circuitous dissolution in the oil case and while the snuff and cigar companies were cut loose in the tobacco decree, the three large successor units were 'full line' companies. All of the successor units in the powder case were 'full line' producers and later the decree was modified to permit one of them to purchase the assets of a noncompeting concern. Explicit disapproval of circuitous integration (involving cameras and films) was voiced in the photographic equipment case, but the decree as finally framed abandoned the notion."

In United States v. International Harvester Company, 248 U.S. 587 (1918) apparently no effort was made to disturb the defendant's production of several types of farm implements. It was only ordered to dispose of certain brands thereof (decree not reported). 
A third decision approving diversification is found in the sequel to the famous Standard Oil case. ${ }^{35}$ In 1931 application was made to the court which had decreed dissolution of the old Standard Oil Company for permission to merge the Standard Oil Company of New York with the Vacuum Oil Company. The former, commonly known as Socony, was chiefly engaged in the marketing of gasoline and kerosene. Vacuum was principally a refiner of high quality lubricants. The court approved the merger of those two successor concerns with the result that both vertical integration and diversification were extended. One of the reasons given for the approval was that there was little real competition between the two concerns. Each produced different products. Accordingly the court said:

It is clear that there are sound business reasons for this merger which are entirely sufficient and are wholly unconnected with any design to create a monopoly. ${ }^{\mathbf{3 6}}$

Thus it is seen that despite vast enlargement of corporate powers under "liberalized" state statutes, there have been few suggestions in the past that diversification was or should be unlawful.37 Possibly Professor Handler may be taken to have hinted that the case of the United States $v$. Reading $\mathrm{Co}^{38}{ }^{38}$ casts doubts upon diversification, ${ }^{39}$ and it is true that some remarks of Mr. Justice Cardozo can be given similar interpretation. ${ }^{40}$ Not until 1941, however, did any court in effect disapprove of diversification as opposed to our anti-monopoly policy.

35. United States v. Standard Oil Company, 47 F.2d 288 (E.D. Mo. 1931).

36. Id. at 310 et seq. Cf. National Industrial Conference Board, Mergers AND TEE LAW 89 (1929).

37. But see dissent in Eckman v. Chicago, Burlington \& Quincy R.R. Co., 169 IIl. $312,324,48$ N.E. 496,500 (1897). A similar objection was raised in the eighteenth century: 1 DAvis, Essays in the Earlier History of AMERICAN Coriporations 388, 429 (1917). For a modern version of the same vague fears, see ARNOLD, THE BotTLENECKS of Business 24 et seq. (1940). Cf. the statutes of mortmain, 1 BLACKSTONE, CoMmentaries on THE LaWs OF ENGLAND 479* (Cooley's 3d ed. 1884); 2 Davis, Essays in the EARLIER HISTORY of AMERICAN CoRporations 317 (1917); Hale, $A$ Field for Corporate Law Revision-Collateral Attack, 11 ILL. L. REv. 1, 8 (1916) ; National Home Building Association v. Home Savings Bank, 181 Ill. 35, 41, 54 N.E. 619,620 (1899).

38. 253 U.S. 26 (1920). A bill was filed to dissolve intercorporate relations under $\$ \S 1$ and 2 of the Sherman Act and upon the commodities clause, 34 STAT. 585 (1906); 49 U.S.C. $\$ 1$ [8] (1946). A holding company had been formed to own a coal company and a railway company operating in and serving the Schuylkill anthracite field, which is the largest of three fields in Pennsylvania. Subsequently, the combination bought an interest in Central Railway Company of New Jersey, one of six carriers serving the Wyoming anthracite field and itself an owner of a coal company. It was held that the combination must be dissolved, emphasis being laid upon the combination of competing railway companies and coal companies (whether the concerns actually competed may be another question).

39. Handler, Industrial Mergers and the Anti-trust Lawe, 32 Cor. L. Rev. 179 at 230 (1932) where it was said: "The conclusion is inescapable that the union of the Reading and the Central interests did not stifle competition in the industry at large; at best it merely eliminated competition between two of the largest factors. No one can read the court's opinion without feeling that what is being forbidden is the combination of giant companies doing a substantial part of the business in their fields."

40. United States v. Swift \& Co., 286 U.S. 106, 116 (1932). 
Now storm clouds are gathering. In 1936 Professor Burns expressed considerable misgivings in regard to diversification. He found that it might have consequences similar to non-price competition from which consumers might benefit little. Buyers might be confused by the spread of one brand name over several unrelated products ${ }^{41}$ and the application of profits to wholly new ventures might invite monopolistic results. ${ }^{42}$

In 1941 there was decided the General Motors case, ${ }^{43}$ in which the court found that General Motors and one of its subsidiaries conducting a business in the financing of automobiles had violated the Sherman Act. The theory was that the two corporations had conspired to compel dealers to use the finance service. The word diversification was not mentioned but an implication of disapproval was clearly present.

More recently the Attorney General objected vigorously to a lower court decree permitting railroad companies to purchase the sleeping car business of The Pullman Company. ${ }^{44} \mathrm{He}$ argued that such an arrangement would make it impossible for anyone else to offer sleeping car service.

In 1949 an important study of monopoly was published by Professor Edwards. His program for maintaining a free, competitive economic system included the elimination of "bigness." His strictures against size were not limited to "horizontal" integration: they specifically included diversified firms. He asserted that such concerns could play one market off against another and disregard short term costs in manipulating resources from one field to another. ${ }^{45}$

Later that same year the Attorney General filed a complaint against the DuPont Company and others. ${ }^{46}$ There he alleged that common control of DuPont, General Motors and United States Rubber

41. In Burns, The Decline of Competition 453 (1936) it is said: ". . . in so far as one product tends, or is deliberately used, to 'sell' another, the buyer is confused in his distribution of expenditure; products sold under the same brand name are not necessarily equally desirable."

42. Ibid.

43. United States v. General Motors Corp., 121 F.2d 376 (7th Cir. 1941), cert. den. 314 U.S. 618 (1941). In that year, too, Illinois enacted an amazing statute prohibiting sales outside the regular course of trade, ILL. REv. STATS. c. 1211/2, § 204 (1949).

44. United States v. The Pullman Co., aff'd per curiam, 330 U.S. 806 (1947). On appeal, the question was whether the railroads should be permitted to own The Pullman Company and thus to furnish sleeping car service as well as coach service to their passengers. In that connection the brief of the United States declared ( $p$. 28): "It is apparent on its face that the rail plan vests in the commonly owned Pullman Company a complete monopoly of the market in the operation and servicing of sleeping cars. . . under the rail plan it would be impossible for anyone else to get into the sleeping car business."

45. Edwards, Maintaining Conpetition: Requisites of a Governmental PoLICY 106 (1949).

46. United States v. E.I. DuPont deNemours and Co., N.D. Ill., E.D. No. 49 C 1071 (1949). Cf. United States v. Lorain Journal Co., CCH TRADE REg. REP. If 61,227 (D. Ohio, 1949). 
resulted in an agreement among those three corporations to trade with each other to the exclusion of outside suppliers. Again the charge was couched in the familiar form of "conspiracy." But the complaint also (perhaps somewhat inconsistently) alleged common control. Hence adverse implications for diversification were inescapable.

A few weeks thereafter a member of the Congress in charge of a monopoly investigation stated that he was opposed to "conglomerate operations." And he denounced the use of profits earned in one industry to diversify into another. ${ }^{47}$ Thus the stage is set for an explicit assault upon diversification as such.

\section{Origins of Diversification and Its Relation to Efficiency}

Before examining specific complaints against diversification it may be well to set forth a general outline of its origins. ${ }^{48}$ Considerations which cause business men to diversify may play a twofold role in analysis of diversification's effects. They suggest the different forms in which the multi-product firm appears. They also throw light on the efficiency which diversification achieves, for often an entrepreneur adds a new product in order to reduce costs. The scale of such economies may be difficult to estimate. We can, however, take account of their nature and proceed to suggest their effect upon the economy as a whole.

Fuller use of existing facilities. If a concern finds a new use for the raw material presently required in its business, diversification may be the result. Thus a maker of glass containers used the same basic material to branch out into the manufacture of glass brick for buildings, glass insulation and glass filters. ${ }^{49}$ "By-products" are another cause of diversification. Thorp found that at least half the products made by 47 out of 50 of the largest companies accounted each for less than half of $1 \%$ of those firms' gross sales. ${ }^{50}$ In other words, minor

47. Celler, Breaking Up Big Business, U.S. News \& World Rep., Sept. 23, 1949, pp. 28,31 .

48. Some general but not too acute discussion of the causes of diversification is found in Whitmore, Shaping 1937 Policies to Side-Step Competition, American Bus., Nov. 1936; The Profits of Diversification, Bus. Week, May 29, 1937, pp. 35, 36.

49. The Profits of Diversification, Bus. Week, May 29, 1937, p. 40. Basic identity of materials led Dow Chemical Company into the magnesium alloy business. Id. at 41 . Similarly, Eastman Kodak Company went into the plastics business. Barnes, What's in a Name, Magazine of Wall Street, April 12, 1947, pp. 30, 32. Exhaustion of the soil led a fruit grower into the production of other crops. ANN. REP., 1948, UNYTED Fruit Co., at 8,21. It should also be noted that the same company owns the "Great White Fleet" of merchant vessels, 25,000 cattle, 17,000 horses, sugar mills, and railroads. Barnes, supra at 32; THORP AND CROWDER, op. cit. supra note 11, at 657 . The Glidden Company, formerly a maker of paint, studied its raw material, linseed oil; then it developed the production of edible oils. Barnes, supra, at 30 et seq.

50. THORP AND CROWDER, op. cit. supra note 11, at 602 . As defined in the census reports, by-products are not important from a revenue standpoint. Id. at 609 . "Joint" products are much more frequent than "by-products." Id. at 170. But the definition of "by-product" requires it to be made in a separate plant. Id. at 174 et seq. 
by-products are important numerically. It follows that they may assume a large quantitative role. Thus a recent annual report says :

In the early part of the century, Diamond acquired extensive holdings of timber lands to provide reserves for the manufacture of wood matches.

Research and experience have demonstrated that the most efficient match production can be achieved by careful selection of match lumber. . . with the rest being sawed for building purposes. . . . ${ }^{51}$

An existing product may be converted to another purpose, thereby enabling a producer to reach new markets. A photographic concern, for example, now makes a device called "Recordak," a specialized camera for use as a business machine. ${ }^{52}$ Changes in the basic product have placed its maker in another "industry."

Existing technology may be applied to produce new devices. Thus a dental manufacturing company entered the field of producing flexible shafting for use upon automobiles, airplanes and other vehicles:

Experience in making flexible tubing for the dentist proved valuable when industrial demand sprang up for similar products, to which the company wisely and rather easily adjusted its schedules. $^{53}$

Observers who find even the broad "chemical industry" narrower than the field of endeavor of Union Carbide and Carbon Corporation have been unable to discover a central theme for that concern's operations. But one writer saw that the development of existing technology accounted for the concern's wide diversification. ${ }^{54}$

51. Ann. Rep., 1948, The Diamond Match Co., at 5 . With every ton of ore extracted primarily for its nickel content, 95 pounds of copper are refined as opposed to 47 pounds of nickel. Gold, silver, and platinum are also recovered. International Nickel, Fortune, August 1934, pp. 64, 68. A concern extracting natural gas from the ground derived $16.7 \%$ of its sales from the vending of gasoline. ANN. REP., 1948, Natural Gas Pipe Line Co. OF America, at 10.

52. Richmond, Profits Out of Pictures, Magazine of Wall Street, Oct. 23, 1937, pp. 24,25 . A machine used by farmers to spray crops was developed into a fog fire fighter and also into a car-wash machine. Food Machinery Corp., A Saga in Diversity, Business Week, April 10, 1948, pp. 88, 92. Cf. The Profits of Diversification, Bus. Week, May 29, 1937, pp. 35, 41 .

53. Barnes, supra note 49, at 31 . See also Waldron, Coming Competitive Clash, Magazine of Wall St., Nov. 9, 1946, pp. 127, 168; The Profits of Diversification, note 52 supra, at 39; Jordan, Profits from Diversification, Magazine of Wall St., Dec. 19, 1936, pp. 300, 301; Minnesota Mining in Motion, Fortune, Mar., 1949, pp. 93, 162; American Smelting \& Refining Ca., ANN. REP., 1948, at 16 et seq.

54. In Union Carbide I: The Corporation, Fortune, June 1941, p. 66 it is said: "To define exactly what the nature of that business is has baffled almost everyone who has tried it, including Union Carbide itself. It ranges through hundreds of seemingly unrelated products. . . It is merely bewildering... to look at this business as a series of products or simply an expression of the American financial will to organize - . Carbide is neither a 'products' company nor a creation of Wall Street, but primarily a process company built upon a few basic techniques. . . ." 
A desire for fuller use of existing tools and personnel may give rise to diversification. At the end of World War I a powder company had a large plant with excess capacity. Gradually it found uses for its factories and tools in the production of soluble cotton for the lacquer, photographic, coated fabric and plastic industries. ${ }^{55}$ A Wisconsin firm makes an assortment of products which seem to bear little relationship to each other. Among them are tanks for transport and storage; dump bodies of various types; oil and gas fired home heating systems; farm and industrial dehydration plants; milk bottle washers; and road making machinery. It is nevertheless claimed that all of the products are built with pre-existing tools. ${ }^{56}$ Even services made available to corporations upon a permanent basis form a foundation for diversification. A large concern may have departments specializing in accounting, finance, law, advertising and the like. The existence of such services may suggest the desirability of diversification. ${ }^{57}$

Vertical integration may lead to entry into new fields. A tire maker had a textile division to produce the cord and fabric needed in its casings. When it converted from cotton to rayon tire cord, it was left with excess textile capacity. Now it makes a branded dishcloth in a part of the textile mills formerly producing tire cord. ${ }^{58}$ The United Fruit Company started its radio business purely as a service to the company's operations in the harvesting and shipment of bananas. It now offers, through its subsidiary, Tropical Radio Telegraph Company, a general communications service to the public. ${ }^{58}$ United States Steel Corporation originally got into the cement business in order to afford an outlet for its slag. ${ }^{60}$ Diversification is greatly encouraged by operational changes in a vertically integrated business resulting in aban-

55. Clifford, Diversified outlets contribute to strong position, Magazine of Wall Street, Nov. 20, 1937, p. 164. THORP and CROWDER, op. cit. supra note 11, at 653 .

56. Local needs influence product planning, Bus. Week, Aug. 14, 1948, pp. 44 et seg. Cf. The Profits of diversification, Bus. Week, May 29, 1937, pp. 35, 39.

57. Armstrong, Top management policies that speed healthy sales grozeth, Sales Management, May 1, 1945, p. 35.

58. U.S. Rubber's two-weyy stretch, Bus. Week, Dec. 11, 1948, pp. 83, 88.

59. United Fruit Co., ANN. REP., 1948, at 22. The Fruit Company's fleet of vessels now carries passengers as well as the company's own freight. Id, at 23. White Castle System, Inc., an operator of hamburger dispensaries, entered the production of a prefabricated steel building which it made primarily for its own use. It also made paper caps for its employees. Now both products are sold to others. The Profits of diversification, supra note 56, at 40 . Bethlehem builds ships, some of which carry ore from its own mines to its own steel mills. Bethlehear SteEl CoRp., ANN. Rep., 1948, at 6,20. Use of diversification and vertical integration on a complementary basis is illustrated in The Diamond March Co., ANN. Rep., 1948, at 5.

60. U.S. Steel: I, Fortune, March 1936, pp. 59 , 184. Vertical integration by the major automobile manufacturers deprived some of the accessory producers of their markets. They therefore turned to other fields. Applegate, Earning power of motor accessory industry upheld by wide diversification, Annalist, Oct. 26, 1939, p. 531. Vertical integration may also cause diversification when the acquired firm has a sideline. THORP and CROWDER, op. cit. supra note 11 , at 655 . Foreclosure of mortgages and similar operations may likewise result in diversification. Id. at 657. 
donment of a raw material. Thereafter it must be sold to some outsider or processed in a different manner. ${ }^{61}$

Sales promotion. As we have seen, diversification may result from attempts to make use of existing facilities. Entrepreneurs may also go into new lines of business as an attempt to improve sales of their original products. Complementary merchandise is often produced with such purposes in mind. Thus it has been said:

The Eastman Kodak Company makes cameras and, incidentally, money on them. But it makes them mainly as a sideline that photography may grow in popularity and usefulness and thereby widen the demand for film. ${ }^{62}$

Public utilities engage in the sale of appliances which will utilize their principal products. ${ }^{63}$ In some instances a manufacturer desires to preserve the good will in the machinery he has sold by supplying articles for use with it. ${ }^{64}$ In the General Motors case ${ }^{65}$ the automobile manufacturer sought to justify its entry into the business of financing the sale of cars by showing that the "unethical" practices of other financers would hurt its good will. Indeed, it succeeded in showing that it had originally entered the financing business almost wholly for the convenience of its customers. At that date there were scant other facilities for the sale of automobiles "on time." 66

Sometimes the manufacturer wants to "round out his line" because the business policy of carrying "a full line" meets the convenience of distributors or consumers. If important customers demand varied items, a manufacturer or distributor may supply them. ${ }^{67}$ Since most of the big buyers of steel require a variety of steel products, steel com-

61. ThORP and CROWDER, op. cit. supra note 11, at 656 .

62. Richmond, Profits out of pictures, Magazine of Wall Street, Oct. 23, 1937, p. 24. Cf. Alexander Milburn Co. v. Union Carbide \& Carbon Corp., 15 F.2d 679 (4th Cir. 1926) cert. denied, 273 U.S. 757 (1927). American Can Company developed machinery to sell cans in order to stimulate their use. Now it sells such machinery to canners. AMIERICAN CAN CoMpany, ANN. REP., 1948, at 246. A manufacturer of sprayers went into the insecticide business in order to provide a product which could be used with its original item. Food Machinery Corp.: $A$ saga in diversity, Bus. Week, April 10, 1948, pp. 88, 93.

63. About $8.65 \%$ of a utility's gross receipts were obtained from the sale of appliances and about $12 \%$ from the sale of by-products. Peoples Gas Light \& Coke Company, 1948 ANN. Rep., at 31.

64. THORP AND CROWDER, op. cit. sipra note 49, at 652

65. United States v. General Motors Corporation, 121 F.2d 376 (7th Cir. 1941), cert. denied, 314 U.S. 618 (1941).

66. Id. at 386. As to another industry it has been said: ". . . it has been recognized that, with a return to more normal conditions, the volume of time sales would increase. . . The Company must always be prepared to supplement existing agencies in this financing to whatever extent may be required to obtain desirable business. One method under consideration is the establishment of a subsidiary finance company to assist in carrying out this function." INTERNATIONAI HARVESTER CoMsPANY, 1948 ANN. REP. at 6.

67. ThORP AND CROWDER, op. cit. supra note 11, at 651, 656. 
panies for years have set up their sales offices and trained their salesmen to sell the whole line of products. ${ }^{68}$

In other instances, additions to the sales "line" have been motivated by a desire to economize. In other words, sales costs are heavy and it is believed that they may successfully be spread over a larger number of products to result in lower unit costs. Thus a glass company entered upon the manufacture of paint:

The production of these [paint] items on a large scale has been logical because paint stores generally feature glass as well, thus encouraging distribution of the dual line. ${ }^{69}$

In almost the converse situation a small firm may merge with a larger one in order to secure the advantages of an existing system of distribution. ${ }^{70}$ Of course diversification, in order to "round out" a "sales line" and to reduce selling costs may be overdone. A firm with three separate brands of the same item would seem to have carried the notion into mere conglomeration for its own sake. ${ }^{71}$ Indeed, there are hints that the attainment of "prestige" has had something to do with "rounding out the line." 72

Exploitation of the value of trade marks leads to sales diversification. An interesting illustration is that of the Rieser Company, Inc., a concern engaged in the manufacture of "Venida" hair nets. During the period 1922-1930, bobbed hair replaced earlier styles and the sales

68. U.S. Steel: I, Fortune, Mar. 1936, pp. 59, 184. As to the car-washer made out of an insecticide sprayer, it has been said: "Food Machinery also converted the basic sprayer into an efficient car casher. Selling it, though, wasn't so easy. Salesmen reported they needed a broader line of automotive service equipment... so the engineering department developed an auto wheel aligner and a wheel balancer. Now all three items enjoy brisk demand," Food Machinery Corp.: A Saga in Diversity, Bus. Week, Apr. 10, 1948, pp. 88, 92.

69. Barnes, supra note 49 at 31. Cf. Kelley, Chain store merchandising ideas helped this little business grow, Sales Management, Aug. 1, 1945, pp. 103, 164, wherein it was said: "At first glance, it might seem that Testor Chemical Co. has expanded in a haphazard way. But upon analysis, it becomes evident that the expansion has been along these lines: (1) as a result of intensive research into allied fields; (2) into fields in which sales outlets have already been well established."

A manufacturer of candies added soft drinks, muffin mix, potato chips and other foods because it was already distributing its wares to grocers. Schnering, Facts Behind the Curtiss Candy Program of Line Expansion, Sales Management, Nov. 1, 1943, pp. 24, 25-26.

70. Philco Corporation, letter to stockholders (March 14, 1949) wherein the acquisition by Philco of the assets of Electromaster, Inc., was described as follows: "This transaction was a good one from the point of view of both companies. To the Electromaster shareholders, it gave broader diversification through representation in a number of different fields and the strength of the Philco distributor-dealer organization. The acquisition of Electromaster enabled Philco to enter the electric range field with an accepted product, modern plant facilities and a highly efficient organization. To our former line of products ... we have now added electric ranges, a field which offers very attractive opportunities for growth and development."

A big firm may also acquire a smaller one to market some one product. Food Machinery Corp.: A Saga in Diversity, Bus. Week, Apr. 10, 1948, pp. 88, 93.

71. Ecko Producrs Co., Ans. ReP., 1948, at 6.

72. Food Machinery Corp.: A Saga in Diversity, supra note 70 , at 92. 
of hair nets declined drastically. The company thereupon entered into the production of hair pins and allied products, such as shampoos, applying its trade mark to those new items. Diversification worked so well that it later extended its line to include cleansing tissue. ${ }^{73}$ An officer of the concern said:

Our purpose was to make a double play on our trade mark. Identified with an established trade name, we felt that these two products would benefit from an immediate acceptance. ${ }^{74}$

Apparently makers of women's dresses are now entering the perfume and cosmetic field. Manufacturers have decided to take advantage of their names in the way it has been done in France. ${ }^{75}$

Research and security. There are, of course, instances in which diversification is a positive policy: it seeks additional profit rather than negative elimination of waste. Many corporations, for example, carry on a continuous program of industrial research. In studying one problem, they often hit on variations which can be applied to create new products. ${ }^{76}$ So intensive is the industrial research carried on by some corporations that diversification flows in an unending stream. One company sold nine million dollars worth of products in 1948, all of which had been developed in its own laboratories within the two previous years. ${ }^{77}$ In 1937, 58\% of the net income of a prominent chemical manufacturer was derived from the sale of products developed in its own laboratories since $1919 .{ }^{78}$ Diversification results from research because by-products are frequently more important than the items sought. And since research is a deliberate policy, it must also be considered that the diversification it causes is deliberate in character. ${ }^{79}$

73. Rieser, When Hair Nets Flopped, Printer's Ink, Jan. 24, 1935, pp. 56, 57.

74. Id. at 57. Concerning the venture of a miller in the home appliance field, it has been said: "General Mills went into the appliance field partly because of Maurice H. Graham, 59 year old inventor of the Toastmaster, whom it had retained in 1943. His first idea: Capitalize on Betty Crocker's famous name. The upshot came in 1946; The Betty Crocker Tru-Heat Iron." Diversification Pays Off, Bus. Week, Feb. 28, 1948, pp. 66, 74. A survey showed that General Mills' trade mark was known to $91 \%$ of all housewives. $I d$. at 76 .

75. In some instances trade marks have been broadcast over unrelated products. Fairbanks, Morse Steps Out, Bus. Week, Apr. 28, 1934, D. 10 (Maker of scales added windmills, gas engines, pumps, radios, washing machines, refrigerators). $C f$. the case in which a company starts to produce its old product from a wholly new raw material. Texas Gulf Sulphur Company, Ann. Rep., 1948, at 3.

76. THORP AND CROWDER, op. cit. sipra note 11, at 648; ABBOTT LABORATORIES, ANN. Rep., 1948, at 3.

77. Minnesota Mintng \& Manufacturing Company, Ann. Rep., 1948, at 10.

78. Devlin, Making Diversification Pay, Magazine of Wall Street, Nov. 5, 1938, p. 88. Celanese Corporation OF America, AnN. Rep., 1948, at 18.

79. General Mills, Inc., 20th ANn. Rep., May 31, 1948, p. 34, wherein it is said: "The research philosophy of General Mills is summed up in the words of James F. Bell: 'You can influence research environmentally, but you cannot lead it. You must follow where research leads." "

In General Mills' Horizons, Feb. 1949, p. 9 it was said: "We see no good reason for limiting ourselves to food products. Our research explores possibilities in many 
Deliberate adoption of diversification also occurs when a company is concerned that a substitute product may capture its market. When can companies started to market special cans for beer, a prominent maker of glass beer bottles jumped into the business of making tin containers. ${ }^{80}$ As Professor Burns said, integration into substitute products starts with a desire to reduce risks. The firm is impelled to enter the production of goods and services likely to displace its existing products. ${ }^{81}$ And to a certain extent the production of substitutes is akin to the broadening of trade marks to cover new products.

Stabilization. Perhaps more important is the effort to stabilize business. Diversification has long been urged as a means of avoiding both seasonal and cyclical slumps in sales. To avoid the seasonal character of the ice trade, a prominent corporation went into the business of selling coal and oil..$^{82}$ A manufacturer of Christmas tree lights, sold only in the holiday season, expanded its output so as to produce stoves, refrigerators, freezers, kitchen cabinets, automobile lamps and explosives. ${ }^{83}$ Efforts to bridge gaps of the business cycle are perhaps even more important as a cause of diversification than efforts to avoid seasonal slumps. Many of the depression troubles of a prominent maker of electrical equipment were blamed upon its concentration in producers' goods. It was suggested that the concern diversify so as to make radios, refrigerators and other items sold directly to ultimate consumers. ${ }^{84}$

Imperceptibly a desire to stabilize may become an urge to allocate resources into greener pastures. As the demand for cigars declined, a

fields. . . Research led us into the chemical field where we are now extracting and processing oils. We believe that diversification will assist us in building a stronger and better company."

80. The Profits of Diversification, Bus. Week, May 29, 1937, pp. 35, 40. Cf. Consumers' Gas Trust Co. v. Quinby, 137 Fed. 882, 896 et seq. (7th Cir. 1905).

81. BuRNs, The Dectine of Conpetition, 454 (1936).

82. City Ice Diversifies, Bus. Week, May 18, 1946, p. 73; Donaven, We Are Stabilizing Employment, 92 Factory Management and Maintenance, Nov. 1934, pp. 480,481 .

83. Santa Claus Diversifies, Bus. Week, Dec. 28, 1946, pp. 56, 60. The Profits of Diversification, Bus. Week, May 29, 1937, pp. 35, 39. Gates, Diversity of Output the Key to Recovery, Magazine of Wall Street, Jan. 5, 1935, pp. 328, 329. Other examples are found in Diversification Smooths Cycle of National Acme, Barron's, March 21, 1949 , p. 35,135 . Gillette Begins to Diversify, Bus. Week, Jan. 10, 1948, p. 44 . On the other hand, Thorp found the trend toward diversification stronger during the period 1920-1933 than during the period 1933-1939. THORP AND Crowder, op. cit. supra note 11, at 660 . He also pointed out that the cause of diversification does not necessarily indicate why a firm selects a particular new product. Id. at 646 . See also Ex-Cello-O-Corp., ANn. ReP., at 4 (1942).

84. Efforts are frequently made to depart from the production of highly cyclical producers' goods into the making of consumers' goods. Baird, Wider Line of Products Pulls Evans Out of the Red, Sales Management, Feb. 15, 1934, p. 135. (Concern making product to load automobiles on railway cars turned to manufacture of separators for automobile batteries; etc.) ; The Profits of Diversification, Bus. Week, May 29, 1937, p. 38; Stern, Borg-Warner Makes Diversification Pay, Magazine of Wall Street, July 18, 1936, p. 409. 
tobacco manufacturer went into the wine business. ${ }^{85}$ When air conditioning was first introduced, many existing concerns, including two automobile manufacturers, ${ }^{86}$ hastened to enter the new field. A desire to get in on the ground floor of a new industry ${ }^{87}$ and the urge to avoid rigorously competitive markets are both factors to be considered. ${ }^{88}$ An important maker of radio sets went into the refrigerator and air conditioning business because profit margins on its existing production were low. ${ }^{89}$

Multiple causes for diversification. It must be plain that more than one of the foregoing factors may be a simultaneous cause for diversification. For example, a prominent maker of matches also makes and sells toothpicks, paper towels and other paper products. They are made out of the same raw material as matches and are sold through the same channels. ${ }^{90}$ An amusing case which rings almost all the changes upon the asserted virtues of diversification is that of Globe Union, Inc., formerly a maker of batteries for farm, automobile and radio use. Its expansion into new lines of production was explained in the following terms:

It was decided to seek additional lines which would tend to level out production and steadily employ our . . . equipment. Because [facilities were available] . . . we took on the manufacture of spark plugs. Spark plugs are distributed through the same channels as automotive batteries and the demand is fairly constant. With punch-press and screw machine equipment available, we further diversified by adding roller skates, the sale of which is in seasonal peaks opposite from battery peaks. Development of roller skates led to making a beginner's ice skate and later a roller scooter set (all of which fit into toy and sporting goods markets). Our automotive lines require manufacture of other

85. The Profits of Diversification, Bus. Week, May 29, 1937, pp. 35, 37.

86. Id. at 37.

87. Id. at 37 .

88. Mimesota Mining in Motion, Fortune, March, 1949, pp. 93, 162.

89. Philco Diversifies, Bus. Week, March 18, 1949, p. 23; Diversification Pays Off, Bus. Week, Feb. 28, 1948, pp. 66, 68. It is said that General Mills makes a low margin of profit on flour milling and it is attempting to improve its position by diversification into packaging machines, vitamin concentrates, household appliances, refineries for soybean oil, fatty acids, farm feeds, etc. Id. at 66 et seq. A revealing statement is that of the American Brake Shoe Company: "Over a period of years, we have been following the policy in our foundry Divisions of adapting a substantial part of their capacity to the production of more specialized and complex products. This has been done to achieve a more balanced output between the standard foundry items and special products." American Brake Shoe Co., ANN. Rep., 1948, at 15.

90. The Diamond Match Co., ANn. Rep., 1948, at 5. In December 1948 the McGraw Electric Company acquired two other concerns: "This acquisition had a double objective. The first was to diversify our company's position and amplify its scope of operation. The second was to avoid current excessive building and equipment costs for major plant expansion by acquiring profitable going concerns . - ; both badly needed to round out our company's line of small electrical appliances. . . ; McGraw Electric Co., AnN. Rep., 1948, at 2. 
items, such as battery test equipment, spark plug testing and cleaning equipment and spark plug gap gages. ${ }^{91}$

Effect of political forces; involuntary diversification. Some diversification results from forces beyond the control of corporate management. Indeed, there are causes of diversification which are noneconomic in character. Take, for example, the effect of war. Many corporations expanded their plants in order to take war contracts. After hostilities ceased, the entrepreneurs sought uses for the additional plant. $^{92}$ In the period following World War II many makers of aircraft expanded into new lines of product. One, for example, despite the unfavorable experiences of its competitors, branched out into the refrigerator business. ${ }^{93}$ Machine tool manufacturers also have been compelled to find uses for excess capacity born of war necessity..$^{94}$ Once war has caused the creation of excess capacity, the resultant diversifcation is simply a question of making that fuller use of facilities suggested above. Political considerations may also suggest the desirability of engaging in new enterprises using raw materials produced by large voting blocs. ${ }^{95}$

Impact of taxtion. Another important political cause of diversification is found in the federal tax structure. At the present time the combination of normal and surtaxes results in a $38 \%$ direct levy upon corporate earnings. ${ }^{96}$ At the same time rates on individual incomes are steeply graduated. An individual with $\$ 2,000$ of income pays $19 \%$ on additional earnings. Over $\$ 8,000$ the rate is $31 \%$; over $\$ 16,000$

91. The Profits of Diversification, supra note 85 , at 38.

92. Munitions Makers Venture Into New Lines to Use War Plants and Experience, Barron's July 9, 1945, p. 1. A builder of battleships went into the automobile and radio business. Ibid.

93. Hellman, Bell Aircraft Would Take on New Lines, Barron's, Apr. 18, 1949, p. 41. Cf. Waldron, Coming Competitive Clash, Magazine of Wall Street, Nov. 9, 1946, p. 127. Pressed Steel Car Co., a railway equipment manufacturer, expanded into the production of household appliances, air conditioning, and refrigerators. Note 92 supra.

94. The Warner \& Swasey Co., ANn. ReP., 1948, at 3: “. . . we have been undertaking the conversion of a part of our operations to the manufacture of products other than machine tools. This is in line with our long-range program for the utilization of added plant and equipment acquired during the war." General Mills expanded its machine shop in wartime and now makes machinery for printers, canmaking equipment and the like. Barnes, What's in a name? Magazine of Wall Street, April 12, 1947, p. 30.

95. General Mirls, Inc., 16th Ans. Rep., 1944 at 4: "Several important new products will come in a relatively new field, that of the non-food use of agricultural products. Finding new industrial uses for farm products is an avowed research project for General Mills . . . Extension of activities into the non-food uses of agricultural products bears promise of future benefit to the company. It will also help to create a more stable market for the farmer, give him a greater return for his investment of capital and labor, and help to maintain his buying and producing power."

96. Int. Rev. Code $\S \S 13,15$. Nelson, Double taxation legal but unfair, N.Y. Times, Aug. 21, 1949, §3, p. 1, col. 4. 
the rate is $47 \%$; and above $\$ 44,000$ the personal tax is $69 \% .^{.7}$ Computation shows that the effective rate of total tax on dividends in the lowest bracket is about $49.8 \%$. If the shareholder already has income of $\$ 8,000$, a similar computation shows the effective rate of tax to be about $57.2 \%$. With income over $\$ 16,000$, the effective rate rises to $67.1 \%$ and when the shareholder already has $\$ 44,000$ of income, his dividend is taxed at $80.7 \%$. Even if the earnings of the corporation can somehow be transmuted into capital gains of a long term variety, the shareholder will still pay $25 \%$ of his dividends out in $\operatorname{tax}^{98}$ Accordingly, the effective rate of taxation upon the corporate earnings will be above $50 \%$

Another tax factor which may bear on the popularity of diversification is the limitation upon deductions for capital losses. ${ }^{99}$ A going concern may be able to absorb a considerable expenditure for developing new products against its current gross receipts. If an individual subscribes to stock in a new venture, he will receive only $\$ 1,000$ of tax benefit against ordinary income in the event of total loss.

Stiff penalties are attached to the accumulation of corporate earnings beyond the needs of the business. ${ }^{100}$ It can hardly be imagined, however, that the tremendous burdens imposed on shareholders in the declaration of dividends are overlooked. If the corporation can reinvest the earnings with any profitability whatsoever, the result will almost inevitably be advantageous to the shareholders.

Such taxation encourages debt financing. When taxes are steeply "progressive" return from investment becomes less important. Investors prefer to avoid risks and seek the shelter of bonds, particularly those which are tax-exempt. There is reason to believe that the current rate of taxation has so depressed equity values as to make the acquisition of going concerns cheaper than new construction. ${ }^{101}$ In 1948 and 1949 it was not uncommon for one corporation to acquire another for less than the reproduction cost of its tangible plant after

97. INT. Rev. CODE $\$ 12$.

98. INT. Rev. CoDE $\$ \$ 117$ (a), 117(b).

99. INT. REV. CODE $\$ \$ 23(\mathrm{~g})(1), 117$ (d) (2).

100. InT. REv. Cone § 102. UU.S. Treas. Reg. 111, §29.102-3 (1943) provides: "An accumulation of earnings or profits ... is unreasonable if it is not required for the purposes of the business . . The business of a corporation is not merely that which it has previously carried on, but includes in general any line of business which it may undertake. However, a radical change of business when a considerable surplus has been accumulated may afford evidence of a purpose to avoid the surtax . .."

101. McGraw Electric Co., ANN. Rep., 1948, at 2. Cf. Adams, How low-or high-are stock prices? Taxes spell the answer, Chicago Journal of Commerce, May 9,1949, p. 1, col. 3-7. Deductibility of interest is another factor which may be important. INT. REv. CoDE $\$ 23(\mathrm{~b})$. Taxation also affects a concern's ability to extricate itself from diversification. The Commissioner of Internal Revenue has insisted that distribution of General Motors stock to DuPont shareholders would constitute taxable income both to the corporation and to its stockholders. Damned both ways, Fortune, Feb., 1949, p. 15. 
depreciation. Perhaps current rates of federal income taxation are encouraging dissipation of capital: those whose savings would normally be available for equity financing may be spending their principal. If that is true, the supply side of the market has been augmented, forcing values down. Whatever the cause, depressed equity values may encourage diversification rather than expansion of current production because the acquired concern's products are rarely identical with those of the purchaser. And it is worth noting that the Internal Revenue Code does not discourage the formation of subsidiary corporations. Eighty-five per cent of the dividends received by one corporation from a domestic corporation subject to tax are credits to the taxpaying stockholder. ${ }^{102}$

\section{Benefits of Diversification}

In the foregoing survey an attempt has been made to discover the origins of diversification. In many instances it would seem that additional products had been added mainly to reduce costs. In other cases a more positive effort to create additional earnings can be discerned as a motivating force. Involuntary diversification may be caused by political factors, among which the impact of federal taxation is perhaps the most important.

Some of the forms of diversification thus adopted are clearly beneficial to the economy as a whole. In the first place, certain efficiencies undoubtedly result from the production or distribution of several products. ${ }^{103}$ Such full utilization of raw materials as is encompassed in the production of by-products seems almost certain to avoid waste. ${ }^{104}$ Similarly, distribution of several products through the same channels has afforded enough customer convenience to assure the success of mail order houses and department stores. Some types of diversification resulting from vertical integration may cause substantial savings and if we were to forbid the use of existing technology in new ways, we should prevent firms from making full use of their real assets (despite the fact that the balance sheet does not show them). Even apart from economies within a plant, diversification may be efficient. Thus use of

102. INT. REv. CODE $\$ 26(\mathrm{~b})$. But cf. $\$ 117$ (d) (1) (corporations not even allowed $\$ 1,000$ capital loss against ordinary income).

103. THORP AND CROWDER, op. cit. supra note 11 , at 178 . Even within a single plant, diversification may produce economy. Id. at 663 .

104. Cf. Attorney General v. Pere Marquette Railway Co., 263 Mich. 431, 248 N.W. 860 (1933) (surplus property may be used without violation of doctrine of ultra vires). As for the necessity of diversification to create new products, compare Conant, One or many lines? Barron's, July 8, 1940, p. 7, where it is said: "There must be fairly constant input into a business against the ravages of fading-out demand. $\therefore$. We cannot get all set on our favorite product and sink or swim on that alone. Sooner or later it may get water-logged and fail to keep us afloat. We cannot hope always to find intimately related lines in which to expand. We may have to seek new trade entirely..." 
similar tools to produce commodities varied by the season may cut $\operatorname{costs}^{105}$ and it is also possible that the element of transportation charges will create a similar effect. ${ }^{108}$ As we have seen, some firms are spreading services over a large number of products. Legal, financial and marketing services may be allocated to a number of different commodities in an effort to reduce overhead costs. ${ }^{107}$ Of course all the foregoing considerations scarcely apply to concerns producing wholly unrelated products. ${ }^{108}$

One school of thought favors the spreading of risks. Andrew Carnegie, on the other hand, was quoted as urging businessmen to put all their eggs in one basket and to watch the basket. Those two divergent theories may be compared to the views that experience is the most important factor in business success ${ }^{109}$ and its opposite, the belief that intelligence, industry and judgment will produce favorable results in any field. It is difficult to suggest any test of efficiency in the varying degrees of diversification. Every change is likely to increase some costs as it decreases others. In other words, efficiency is a question of balance which can only be ascertained, if at all, from a study of practical effects. It is sometimes said that the United States Steel Corporation is so large that it is inefficient. As evidence of such inefficiency, it is shown that the company has progressively lost part of

105. Thorp AND Crowder, op. cit. supra note 11, at 664 .

106. If freight costs are high, diversification may become efficient even though specialization within the plant would otherwise be more desirable. Diversification can result in greater production and better market coverage, Brick \& Clay Record, July 1944, p. 18.

107. In the period 1935-1945 American Home Products Corporation added 27 formerly independent concerns to its assets. Each former concern enjoys considerable independence. As to various services, however, it was said: ". . all subsidiaries, while exercising a wide degree of autonomy, share in and may draw upon a vast pool of marketing experiences, and top-flight talent to expedite any program or assist with any problem. Greater benefits through research and economies in production and distribution are thus realized ..." Armstrong, Top management policies that speed healthy sales growth, Sales Management, May 1, 1945, p. 35 . An interesting statement of a similar situation concerning a firm called Continental Industries is found in Strength in unity: Continental Industries is uniting well-established small businesses, Bus. Week, Oct. 7, 1944, p. 66.

108. Cf. Daly, Cotton and woolen mills in big merger, Manufacturers' Record, Oct. 1946, p. 69 (assertion that merger of cotton, woolen and rayon mills was expected to effect operating economies). And spreading of common costs may give rise to difficulties. Burns, The Decline of Competition 450 (1936). Cf. the controversy concerning the allocation of costs within the Tennessee Valley Authority. By allocating a large part of the capital expense to flood control, navigation, etc., it is possible to reduce the "cost" of electricity to a low level. Roberts, Certain Aspects of Power Irrigation and Flood Control Projects, TASK FORCE REPORT TO COMMISSION on ORganization of THE ExEcutrve BRANCH OF THE GovernMent 15 et seq. (1949). But cf. Acheson et al. dissenting in Hoover ( $\mathrm{Ch}$.), Comarission on ORGanization of Executive Branch of GovernMent, Reorganization of Federal Business EnterPRISE 106 et seq. (1949) (denial of assertion that costs should be allocated upon economic basis). See text infra, at notes 197-207.

109. The late J. O. McKinsey, an efficiency expert called to the chairmanship of Marshall Field and Company, was quoted as favoring concentration of that firm's endeavors within narrow limits. Acting upon that theory, the company sold another department store which it operated and reduced its wholesale business. Field sells a store, Bus. Week, May 29, 1937, p. 34. 
its market to smaller rivals. Such a concern faces a difficult problem when it is tempted to expand into a new field of endeavor. ${ }^{110}$

Another important benefit of diversification is that it increases competition. Entry of the Chrysler Corporation into the air conditioning business must have stiffened competition in that industry more than the creation of a new firm would have done. ${ }^{111}$ Professor Edwards took account of this favorable aspect of diversification. ${ }^{112}$ As Thorp said, "mobility is increased," $i$. e., resources are rapidly shifted to more economic uses. ${ }^{113}$ And he found that half of the companies studied which diversified into new products created new facilities to do so: there was not merely a change of ownership resulting in aggrandizement of an existing concern..$^{114}$

It seems likely that diversification adds to the stability of individual firms. Avoidance of seasonal patterns of business, for example, would seem to reduce risks of failure. Similarly, the circumvention of cyclical fluctuation must tend to preserve existing concerns from the grasp of bankruptcy. ${ }^{115}$ There is, of course, a tremendous variation in the

110. U.S. Steel: I., Fortune, March, 1936, p. 59. U.S. Steel: Into Chemicals? Bus. Week, Apr. 10, 1948, p. 30. It is often said that a specialized concern can operate more efficiently than its diversified competitor. "Many large companies attained their greatest growth, in other words became big, when they were one-line businesses . . . Bigness gave them greater diversity and strength, but it also gave them disadvantages which they did not have when they were small. The company with a small line of products can throw all its resources into making that line profitable. It has nothing else to worry about. Often the large company has to scatter its efforts over so many activities that on the average only some of these activities result in a profit. Other activities pile up losses that partly or entirely offset the profits being made in some divisions." Murphy, The Simple Business Is Best, Barron's, Jan. 8, 1940, p. 7. In the last analysis the problem is undoubtedly one of balance.

111. THORP AND CROWDER, op. cit. supra note 11, at 668 et seq.; Ways to skin a cat, Bus. Week, Nov. 24, 1934, p. 12.

112. Edwards, An Appraisal of the Antitrust Lazos, 36 Proc. Am. Econ. Assn. 172,187 note 1 (1946). An interesting statement has been made concerning the introduction of the insecticide D.D.T.: "Many [chemical] firms hastened to make the remarkable insecticide DDT when it first appeared on the market. It wasn't long before supplies were more than adequate and the price came down. Only a few big firms with favorable costs : - fared well in the final accounting." Self, Soft Spots and Competition Appear in Chemeal Sales, Barron's, Apr. 25, 1949, p. 9. Cf. Conant, The Internatioñal Harvester Co. 189 (1913).

113. THORP AND CROWDER, op. cit. supra note 11, at 669 et seq. Sometimes exclusive dealing arrangements are defended upon the grounds that they are necessary to give a dealer an incentive to buck an established monopoly. See the statement of Senator Walsh, 15 Cong. Rec. 14,097, 14,098 (August 21, 1914).

114. THORP AND CROWDER, op. cit. supra note 11 , at 661 .

115. Burns, THe Decline of Competition 450 (1936); Stabilizing the Brass Business, Fortune, July 1949, p. 70; Bowen, Big Chemical Companies Outzeit Business Decline, Barron's, Nov. 14, 1949, p. 11. As to cyclical changes, compare the following statement: "When a specialized enterprise is caught with a product for which the demand is disappearing, its demise is apt to lead to a definite break in employment both of men and machines. In the case of the large multi-product enterprise, on the other hand, there is more likelihood, though no certainty, that the transition can be carried out in an orderly way with a maximum of salvage." Thorp AND CROWDER, op. cit. supra note 11, at 665 . Professor Dewing, on the other hand, was more than skeptical of industrial consolidations as a means of warding off depressions. Dewing, The Financial Policy of Corporations 765 (3d ed. 1934). He said: "And, as in the earlier periods of the eighteen nineties, the professional economists acquiesced in the presumption that combinations were a means of sup- 
cyclical patterns of different industries. For example, the 1932 production of steel rails was only $14.7 \%$ of the 1929 figure, but in 1932 the tobacco companies produced about $93 \%$ of the cigarettes they had rolled in 1929.116 A concern with a foot in each industry, therefore, would seem to be less vulnerable to cyclical hazards than one wholly concentrated in the less stable business.

To the extent that each firm is more stable it would seem likely that employment would fluctuate less. And if machines and inventories are not dumped on markets at distress sales, prices generally would be less likely to swing between extreme positions. Thus it can be argued that stabilization of individual firms results in stabilization of the economy as a whole. The fact that underdeveloped areas of the world are constantly striving toward diversified production lends credence to that conclusion. ${ }^{117 a}$

\section{Attacks and Analysis}

If the above outline of the causes and benefits of diversification is sound, we shall be better able to appraise the complaints against diversification set forth below--complaints which relate to the existence of alleged monopoly. The charges set forth do not, however, include

pressing competition, so now the contemporary theoretical students see in the continued merging of corporations a groping after stability. But one set of phrases cannot be substituted for another in the hope of discovering a new truth . . . nor can we presume that a stability arising from the presumption that the larger the unit of production or distribution, the greater its vitality, has any lasting reality as an abiding economic truth. Economic laws are made of more robust stuff." As an abstract ideal, bankruptcy may suggest desirable fluidity but in the absence of perfect competition, the losses inherent in bankruptcy are probably real. In addition, there are court costs and delays which can hardly contribute to increased production. It is interesting to note that the courts have usually been wary of giving the mortgagee his pound of flesh. Even in the most obvious cases, the courts have not always squeezed out common stockholders in corporate reorganizations. See Dodd, The Los Angeles Lumber Products Company Case and Its Implications, 53 HARv. L. REv. 713, 734 et seq. (1940). Apparently there is a feeling that the business cycle swings away from "fair" values.

The Gillette Company, which purchased the "Toni" hair waving business in order to diversify its activities and thus avoid cyclical changes, recently reported a decline in its overall profits owing to slack sales of "Toni" products and not to lack of profits in the original razor blade business. Gillette ready to ship new product, Boston Traveler, May 19, 1949, p. 40, col. 5.

116. Chicago Dally News, Almanac 115, 266 (1931); 366, 679 (1934). Of course diversification reduces high earnings in boom times as much as it protects corporate existence during depressions. That fact is recognized by industry. Thus it has been said: "General American will continue to build toward making its business more and more depression-resistant, sacrificing, where necessary, quick profits to gain that end. The leasing business, the backgone of your Company's stable earnings, is expanding on a sound basis. In addition, our diversification in manufacturing makes possible for tus sharply increased earnings. That should result in periods of good business activity." General AMERICAN Transportation Corporation, ANn. Rep. FOR 1947 at 3. The question might well be asked why firms do not hoard cash during boom times instead of diversifying into new products.

117 . Hutcheson, Problems of the Underdeveloped Conntries-I, 24 Foreign Pol. Reps., Sept. 15, 1948, p. 98. Note also that farmers are constantly urged to diversify their crops so as to reduce dependence upon a single commodity. 
every conceivable argument against the multi-product firm: only the more important grounds of attack are considered. After each follows an analysis of its validity.

Tying clauses. One of the chief complaints against diversification is that it leads to the "tying" of one product to another. (Sometimes the phrase "full line forcing" is used instead of "tying.") It is alleged that the diversified manufacturer pre-empts the dealers' shelves. The maker of a single product, even if it is better or cheaper, cannot secure a market. $117 \mathrm{~b}$

In the pre-war assault upon General Motors, ${ }^{118}$ the theory that diversification leads to tying was not advanced in those terms. But such a theory was implied. In that case it appeared that General Motors, a manufacturer of automobiles, had several wholly-owned subsidiaries. Among them were General Motors Sales Corporation (GMSC) and General Motors Acceptance Corporation (GMAC). GMSC was merely an agent for the parent in making the original sales of cars to dealers. GMAC extended credit both to dealers buying from GMSC and to ultimate consumers buying from dealers. Some 375 independent finance companies competed with GMAC. A system of making payment for automobiles on the part of the dealers was so arranged as to favor GMAC: an officer of GMSC held agency powers from each dealer so that he might execute appropriate notes to GMAC. As applied to sales from dealers to consumers, the evidence showed that dealers who failed to use the GMAC service were in danger of losing their "franchises." In other words, General Motors would not sell automobiles unless the dealers compelled consumers to purchase through GMAC. Oddly enough, however, it was found that only $75 \%$ of the dealers were utilizing the GMAC service.

Nowhere in the Attorney General's brief nor in the opinion is it suggested that the mere combination of making motor cars and extending credit to purchasers thereof violated the Sherman Act. Apparently the lack of prior authority caused avoidance of that position. Instead, the whole case was predicated on the theory that General Motors "coerced" the dealers into using GMAC financing. Thus the court said:

When the evidence is boiled down, it is seen at once that the appellants agreed among themselves not to do business with any dealer who would not purchase the retail and wholesale service from GMAC. . . . In the usual case the recalcitrant dealer

117b. Raymond, The Limitist 35 (1947). Cf. Edwards, Maintaining Conpetition: Requisites of a Governmental Policy 104 (1949).

118. United States v. General Motors Corp., 121 F.2d 376 (7th Cir. 1941), cert. denied 314 U.S. 618 (1941). 
had become firmly established in his community and was operating a profitable business, when he was given the ultimatum either to use GMAC or to liquidate his business. ${ }^{119}$

Although every dealer is an independent business man, the supervision and control exercised by GMAC and GMSC over his business operations is almost as complete as if the dealer were an agent in all respects. Every dealer also acquires a substantial investment in buildings, cars, parts and accessories, and builds up good will in his community. Consequently, a cancelled dealership leaves the appellants with one less retail outlet which can be replaced readily, but leaves the disenfranchised dealer without a business and burdened with his substantial investment in the liquidation of which he is likely to sustain a heavy loss. ${ }^{120}$

Conspiracy between GMC and its two subsidiaries was the foundation of the case, although some stress was laid upon the power of General Motors as an important producer of automobiles:

Not only is market control present in the instant case, but a peculiarly pernicious form of it is exhibited.

This becomes apparent at once when it is observed that GMC occupies a dominant position in the automobile industry. . . ..$^{121}$

The court concluded:

. . The necessary and inevitable effect of the coercive conduct tended to produce two distinct restraints of trade, namely a restraint on the commerce in General Motors cars and a restraint on the commerce in instruments of credit. ${ }^{122}$

As every lawyer knows, the practice of tying is prohibited by section 3 of the Clayton Act. ${ }^{123}$ And recently the decisions have tended to apply the terms of that prohibition stringently. ${ }^{124}$ They have suggested that foreclosure from any "substantial market" would bring section 3 of the Clayton Act into play. ${ }^{125}$ Possibly the "substantial market" may consist only of the defendant's own sales. When a patentee has attempted to tie an unpatented item to his patented product,

119. Id. at 399.

120. Id. at 398 .

121. Id. at 403 .

122. Id. at 399. For further history of the automobile finance cases see Ford Motor Co. v. United States, 335 U.S. 303, 306, 312 (1948).

123. 38 STAT. 731 (1914), 15 USC \$14 (1946). The authorities up to 1940 are collected in Hale, Control Over Distribution, 14 Miss. L.J. 170, 177 et seq. (1942).

124. Oxford Varnish Corp. v. Ault \& Wiborg Corp., 83 F.2d 764 (6th Cir, 1936).

125. Note, Tying Restrictions: Changing Standards of Legality, 48 CoL. L. REv. 733,740 (1948). 
the àrrangement has been treated with special severity. Ever since the motion picture patents case ${ }^{126}$ a patentee has been held powerless to compel his licensee to purchase unpatented supplies for use in the patented machine. In fact recent decisions have gone to the extreme of refusing to enforce any rights in a patent if a tying clause is used in connection therewith. ${ }^{127}$

Analysis of tying clauses. It has been suggested-although possibly only indirectly-that diversification results in the "tying" of one product to another. In other words, it is urged that tying clauses are an inevitable concomitant of diversification. Certainly, full line forcing and similar practice may result from diversification, ${ }^{128}$ and, of course, cannot exist without it. An officer of a prominent farm equipment manufacturer was once quoted as saying that his company's policy did not favor full line forcing. He admitted, however, that his salesmen had to be dissuaded from the practice. ${ }^{128}$ And there is something to be said for the view that sellers will take every advantage they can and hence will tie one product to another whenever that is possible. Perhaps Professor Levi had such a thought in mind when he suggested that integration would always lead to abuses. ${ }^{130}$

On the other hand, there is considerable weakness in any argument that diversification inevitably leads to tying. In the first place, the process of "rounding out the line" is not the same as "full line forcing." The former is undertaken on behalf of the customer. Thus in the postscript to the Standard Oil decision whereby Socony was permitted to merge with Vacuum, the court declared: (1917).

126. Motion Picture Patents Co. v. Universal Film Mfg. Co., 243 U.S. 502

127. Note 125 supra at 739. But cf. Federal Trade Commission v. Gratz, 253 U.S. 421, 427 (1920), where it was said: "The words 'unfair method of competition' - . are clearly inapplicable to practices never heretofore regarded as opposed to good morals because characterized by deception, bad faith, fraud or oppression, or as against public policy because of their dangerous tendency to hinder competition or create monopoly."

Arguments against the "tying" of one good to another are found in United Shoe Machinery Corp. v. United States, 258 U.S. 451, 457 (1922) ; Mr. Justice Brandeis, dissenting in Federal Trade Commission v. Gratz, 253 U.S. 421, 440 (1920); STEvens, UnFaIR CoMpetition 75 (1917); Senator Reed, 51 Cong. Rec. 14,091, 14,097 (August 21, 1914) ; Stockhausen, The Commercial and Anti-trust Aspects of Term Requirements Contracts, 23 N.Y.U.L.Q. Rev. 412, 421 (1948); Lewis, Motion Pictures, 11 Encyc. Soc. Scr. 58, 62 (1933); Sen. ReP. No. 698, 63d Cong., 2d Sess. 6 et seq. (1914). There is, of course, an active question as to what constitutes a tied contract as opposed to a combination sale. Note 125 supra, at 742 . Similarly the distinction between tying clauses and "full line forcing" is vague. Cf. Davres, Trust Laws and UNFAIR COMPETITION 322 (1915).

128. Conant, The International Harvester Co. 308 (1913).

129. Ibid.

130. Levi, The Antitrust Lawes and Monopoly, 14 U. of CHI. L. REv. 153, 180 (1947). Cf. Alexander Milburn Co. v. Union Carbide \& Carbon Corp., 15 F.2d 679 (4th Cir. 1926), cert. denied, 273 U.S. 757 (1927) with U.S. v. General Motors Corp., 121 F.2d 376 (7th Cir. 1941), cert. denied, 314 U.S. 618 (1941). If coercion is the natural and inevitable consequence of diversification, it would be difficult to reconcile the two foregoing decisions. 
The struggle for this trade made the pleasure of that customer worthwhile, and such pleasure and convenience soon directed that he be able to procure oil at the same place and time that he bought gasoline. .. . ${ }^{\mathbf{1 3 1}}$

In other words, the consumer requests the manufacturer to "round out the line" for the former's convenience. "Full line forcing," on the other hand, is usually described as a program to, compel a distributor to take merchandise he does not want. Surely there is some inconsistency between the repeated stress laid upon "full line forcing" and the fact that "rounding out the line" is frequently undertaken at the insistence of the dealer. ${ }^{132}$ Although this analysis may not apply equally to all dealers and may be adversely affected by the passage of time, it would nevertheless seem that "rounding out the line" would, to a degree, cancel out the argument based upon "full line forcing."

In the second place, it will be remembered that "rounding out the line" is by no means the only cause of diversification. Take, for example, the case of complementary goods. A complementary product may be used as part of a tying scheme. ${ }^{133}$ On the other hand, it is often provided for the convenience of the customer. It may be a trade necessity arising out of a time lag. When the motive is the convenience of the customer, it scarcely seems possible that tying can be objectionable. A similar argument can be applied to General Motors as a financier of the sale of its automobiles. ${ }^{134} \mathrm{~A}$ railroad which builds a resort hotel along its lines so as to attract passenger traffic can scarcely be said to have created an objectionable monopoly. ${ }^{135}$

$A^{\prime}$ more important factor arises out of the fact that diversification does not always lead to sales in the same market. Thorp and Crowder broke their analysis of diversification down into three principal categories. Those categories were divergent functions, convergent functions and unrelated functions. Under divergent functions they listed joint products, by-products and like processes. Under convergent functions they listed complementary products, auxiliary products and goods made to sell in like markets. ${ }^{136}$ In other words, they distinguished di-

131. United States v. Standard Oil Co., 47 F.2d 288, 300 (E.D. Mo. 1931).

132. Possibly "rounding out the line" may be overemphasized. Thus it has been said: ". . . it may be necessary to sell some articles at a loss in order to offer a 'complete line' to the customer so that he will buy other articles on which a satisfactory profit is earned . . . It is sometimes necessary to follow this plan, but sales departments are likely to over-emphasize the necessity." McKInsey, Busrness ADMINISTRATION 138 (1924).

133. THORP AND CROWDER, op. cit. supra note 11 , at 652 .

134. United States v. General Motors Corp., 121 F.2d 376 (7th Cir. 1941), cert. denied, 314 U.S. 618 (1941).

135. Jacksonville Railway v. Hooper, 160 U.S. 514, 523 (1896).

136. THORP AND CROWDER, op. cit. sipra note 11, at 146. The definitions of these authors should be examined with care. Id. at 147, 149. 
versification arising out of economies in production from diversification aimed at the process of distribution. When functions are "divergent" the products end up in different markets. When functions are "convergent" goods made from varying materials are sold through the same channels. It must be plain that there can be no tying of products when the diversification is of the divergent type. Compare, for example, the first Shoe Machinery case ${ }^{137}$ with the present situation of the International Harvester Company. All of the products of the United Shoe Machinery Company were sold to shoemakers. Thus it was possible to require the customers to take all or none of the manufacturer's products. International Harvester Company sells its trucks chiefly to industry. Its agricultural implements are sold principally to farmers. ${ }^{138}$ The Harvester Company can scarcely be accused of tying the sales of motor trucks to its farm implement business.

Another important factor relates to the existence of some element of monopoly in the principal product to which the ancillary commodity is "tied." In the absence of such an element the two items cannot be tied together. ${ }^{139}$ On the New York Stock Exchange, for example, a seller cannot insist that a buyer take a hundred shares of Standard Oil when he purchases a hundred shares of Dow Chemical stock.

In some instances diversification may result in the tying of one commodity to another. The conditions for such tying are first, that the seller is not "rounding out his line" in a bona fide manner; secondly, that the diversified product is sold in the same market; third, that there is no genuine need for a complementary article; and last,

137. United States v. Winslow, 227 U.S. 202 (1913).

138. Intemational Harvester I: Supremacy, Fortune, Aug. 1933, p. 22. Query whether there is a relationship between tying clauses and the stabilization of industry.

The theory, embodied in $\$ 3$ of the Clayton Act, that tying is monopolistic in nature, has often been disputed. According to one school of thought, buyers retain complete freedom of choice; they can either take the combination of principal and ancillary (tied) goods or leave them. United States v. United Shoe Machinery Co., 247 U.S. 32, 66 (1918); Whitwell v. Continental Tobacco Co., 125 Fed. 454, 461 (8th Cir. 1903); Federal Trade Commission v. Paramount Famous-Lasky Corp., 57 F.2d 152, 156 (2nd Cir. 1932); United Shoe Machinery Company v. Brunet [1909] A.C. 330,343 . Cf. Stevens, UNFaIr Competition 75 (1917); Hale, Trist Dissolution, 40 CoL. L. REv. 615, 625 (1940). Another argument, chiefly applicable to patents, is comparable to the freedom of choice theory. It may be called the "unlimited condition" theory. Mr. Justice Holmes, dissenting in Motion Picture Patents Co. v. Universal Film Mfg. Co., 243 U.S. 502, 519 (1917); Kales, Contracts to Keep Up the Price on Resale and to Buy or Use Other Articles in Comection with Those Sold, 3 CoRNELL L.Q. 89, 97 (1918). Cf. United States v. General Motors Corp., 26 F. Supp. 353 (N.D. Ind. 1939), aff'd, 121 F.2d 376 (7th Cir. 1941), cert. denied, 314 U.S. 618 (1941) plaintiff's supplemental brief in District Court at 19. Such arguments imply the absence of monopoly in the principal product. Federal Trade Commission v. Gratz, 253 U.S. 421,428 (1920); Whitwell v. Continental Tobacco Co., 125 Fed. 454, 460 (8th Cir. 1903); Federal Trade Commission v. Paramount Famous-Lasky Corp., 57 F.2d 152, 157' (2d Cir. 1932). And vice versa: United States v. General Motors Corp., 121 F.2d 376, 400 (7th Cir. 1941), cert. denied, 314 U.S. 618 (1941).

139. Minler, Unfatr Competition 194, 199 (1941); see Standard Oil Co. v.

United States, 337 U.S. 293, 306 (1949). 
that the seller has some monopoly power. In the light of the foregoing limitations, it would seem difficult to prove that diversification inevitably resulted in tying.

Tying clauses otherwise objectionable may be justified when they are merely designed to protect the goodwill of the seller. Another decision ${ }^{140}$ involving the General Motors Corporation held that that concern could require its dealers not to use rival replacement parts in repairing its automobiles. In the opinion of the court the restriction, was justified by General Motors' legitimate desire to maintain good will in its vehicles. It is nevertheless plain that protection of good will does not justify the use of tying clauses when other lawful means would accomplish the same purpose. ${ }^{141}$ Accordingly, in the General Motors case involving the tying of the automobiles to GMAC financing, the court found that other methods would have protected the defendant's good will. In the opinion it was said:

The appellants justify their coercive course of business on the ground that the GMAC service is superior to that of its competitors, and because they fear that unregulated dealers' financing would promote such evils as packing, excessive repossessions and cut-throat methods of competition. . . .

The evidence shows that the coercive conduct in question was not intended to discriminate against an inferior or unreliable finance service. Rather its entire force and effect was directed against any use of any independent finance service. . . .

No doubt it is proper for GMC and GMSC to promote manufacturer's goodwill and to protect the manufacturer against ineffcient and unscrupulous dealers. . . . But there is a limit in law to which a manufacturer may go to control the whole process of distribution. The jury found that the appellants had gone too far with their control plans, and we are inclined to approve and to indorse the jury finding. ${ }^{142}$

140. Pick Mfg. Co. v. General Motors Corp., 80 F.2d 641 (7th Cir. 1935), aff'd per cutriam, 299 U.S. 3 (1936).

141. International Business Machines Corp. v. United States, 298 U.S. 131, 138 et seq. (1936).

142. United States v. General Motors Corp., 121 F.2d 376, 400 (7th Cir. 1941), cert. denied, 314 U.S. 618 (1941). The court continued: ". . . we should think that the appellants would have been able to find a way to punish unscrupulous dealers without penalizing the others at the same time. If in fact unregulated dealers' financing leads to widespread abuses in the retail sale of automobiles, a need indeed would arise for regulation and control in order to protect the public interest. It is doubtful whether regulation in this respect should be entrusted to the dominant manufacturers .. . If in truth some outside control of dealers' financing is necessary, it should originate with the legislators .. "Ibid. Even the Attorney General admitted that the maintenance of good will justified some control over the finance companies. That admission took the form of an attempt to create a regulatory code for the independent financiers. Birnbaum, The Auto-Finance Consent Decree, 24 WASH. U.L.Q. 525, 547 et seq. (1939). 
Even in those instances in which diversification does result in tying, therefore, the result is not necessarily objectionable. The bona fide protection of good will is an approved justification for tying clauses.

Price cutting. A second complaint against diversification is that it leads to selected price cutting. The seller of more than one product may take a loss upon a single item and continue a profitable business by maintaining high prices on his other products. In trade parlance, this is the familiar "loss leader" practice. ${ }^{143}$ In the older anti-trust cases a similar practice was characterized as the use of "fighting brands." In those days a manufacturer, attempting to ruin his competitor, would package his goods in a container similar to those of the rival and sell the "fighting brand" far below cost. ${ }^{144}$

Upon several occasions it has been argued that diversification leads to ruinous price cutting. Mr. Justice Cardozo's reluctance to permit the large meat packers to enter the grocery business was based upon such fears. He laid stress upon the immense size of the packers, saying that the consent decree imposed upon them had been designed to prevent the use of that size to "drive their rivals to the wall." 145 Professor Burns demonstrated that profits from one branch of a business could be used to attempt monopoly in another. ${ }^{146}$ Similar fears of diversification were voiced by Professor Edwards :

. . . an enterprise that sells a wide variety of commodities may select as its victim a concern that specializes in the sale of one or a few of these commodities, and may with impunity undertake a similar program of price cutting limited to the items sold by the specialized concern. In its crudest form such an attack may be pushed so far as to destroy one concern after another and thus to enlarge the attacking enterprise. Less crudely, however, the power to make such localized attacks may be used as a disciplinary device to induce the small concerns to adopt policies that the larger and more diversified enterprise regards as satisfactory. In this form the program is unlikely to require many instances of localized price cutting or to require that these cuts be very deep or very long sustained. The mere power to undertake such a program

143. Edwards, Maintaining Competition: Requisites of a Governmental PoLICY 20, 101 (1949).

144. Davies, TRUST Laws and Unfair Competition 313 (1915). The practice of using "fighting brands" is only a result of diversification if each brand be considered a separate commodity. Otherwise it falls into the category of horizontal integration.

145. United States v. Swift \& Co., 286 U.S. 106, 116, 117 (1932). Partly in recognition of this point of view, the Congress enacted the "commodities clause" of the Interstate Commerce Act, February 4, 1887, as amended June 29, 1906, 34 Stat. 585, 49 USCA $\$ 1(8)$ (1946). Cf. 1 Scharfacan, The InTerstate Commerce Commission 42 (1931). Similar legislation has been enacted in several states. Martin, State Antitrust Laws: LIII (W.P.A. 1940).

146. Burns, The Decline of Competition 451 (1936). 
is sufficient to lend authority to the large enterprise and to persuade the small one that a conciliatory policy is wise. ${ }^{147}$

Analysis of price cutting. If the maker of two products cuts the price of one of them below cost, using profits from the other to maintain his general position, he may be attempting to monopolize the first product. His ability to do so depends upon several conditions. $\mathrm{He}$ must have enough monopoly in the second product to earn high profits. For without high profits he cannot subsidize his attempt to monopolize the first commodity. In the second place, the seller must enjoy a reasonable prospect of successfully monopolizing the first item. Unless he has such a prospect of potential success, he will be making a poor investment. Again, the price-cutter must be prepared to fend off retaliatory action by competitors. ${ }^{148}$ And if the cut prices are subsequently raised in an effort to capitalize upon monopoly achieved, new firms may be attracted into the industry. ${ }^{149}$

A would-be monopolist can finance his effort to control a market from many sources. Subscribed capital may be used to keep an enterprise solvént during a price-cutting foray. Earnings may be hoarded for such a purpose. A company with little working capital may be able to raise cash by means of loans secured by mortgage. Or it may resort to the recently popular practice of selling its plant and leasing it back from the grantee. ${ }^{150}$ There are, in other words, many methods by which funds can be obtained to support an attempt to monopolize. Profits from diversified operations constitute but one means of accomplishing that result. Professor Edwards admitted as much. ${ }^{151}$ Unless, therefore, we are prepared to block all other avenues of raising cash to finance a price-cutting venture, it is doubtful whether diversification should be condemned on that ground.

147. Edwards, op. cit. supra note 143, at 159.

148. Id. at 20 et seq.

149. Burns, op. cit. supra note 146, at 452. Cf. EDWARDs, op. cit. supra note 143, at 95 , where it is said: ". . . Alternatively the need for internal congruity in the policies adopted for different products, channels of distribution, and classes of customers may induce the monopoly to refrain from pressing its advantage in dealing with buyers whose bargaining position is unusually weak; and differences in the products, markets, and distributive channels of a few large enterprises may make collusion relatively difficult. Thus the complex monopoly may be either harsher or milder than the simple one."

150. Cary, Corporate Financing Through the Sale and Leaseback of Property, 62 HaRv. L. Rev, 1 (1948).

151. Edwards, op. cit. supra note 143 , at 169. Cf. Stevens, UNFaIR CoMpetition 43 et seq. (1917). Note that in the use of "fighting brands" as described by Stevens a seller may be competing with himself as well as with his rivals. It should also be observed that the fighting brands theory requires an acceptance of the doctrine that each brand is a separate commodity before it affects diversification. Cf. also United States v. Quaker Oats Company, 232 Fed. 499 (N.D. I11. 1916). 
Possibly price cutting may constitute discrimination of a monopoly type. ${ }^{152}$ And diversification may furnish the foundation for such price cutting. It certainly does not follow that diversification inevitably leads to such conduct: there is nothing to indicate that price cutting necessarily or even probably flows from the existence of diversification. And one can scarcely argue that diversification causes both price cutting and tied sales concurrently. For in a tied sale, the ancillary product is sold at a price above free market levels, while price cutting implies a sale below such figures. In other words, tied sales and price cutting cannot exist together in the same circumstances: either the sale is tied or the price is cut, but both practices cannot exist at once. Thus no one may assert that diversification causes both price cutting and tying unless he refers to different times or places.

Another consideration results from the fact that sales of complementary goods may be made upon a tied basis without an attempt to monopolize. ${ }^{153}$ An aspect of this issue was raised in the well known Gasoline Pump case. ${ }^{154}$ There leading oil companies leased pumps for the dispensation of gasoline at nominal rentals to operators of filling stations, the latter agreeing not to sell rival gasoline from the leased pump. Since the agreement permitted the service station operator to deal in rival gasoline from other pumps, the courts held that neither violation of the Federal Trade Commission Act ${ }^{155}$ nor of the Clayton Act had been proven. The Trade Commission had urged an injury both to other marketers of gasoline who were not in a position to supply pumps at nominal rentals and to makers of the pumps who lost business through the practice. But the courts dismissed those suggestions in summary fashion. Possibly the case would not be followed today, but to the extent that it was soundly decided, it is authority for the view that diversification resulting in the provision of complementary goods below cost is not necessarily the same thing as price cutting with an intent to monopolize: the practice may constitute a mere convenience to the consumer. In essence, it is only an extension of credit. And every firm which extends credit is partly in the banking business ${ }^{156}$

152. Stevens, op. cit. supra note 151 , at 51. Cf. Robinson, The Economics of IMPERFECT COMPETITION, c. 15 (1936).

153. THORP AND CROWDER, op. cit. supra note 49, at 667.

154. Federal Trade Commission v. Sinclair Refining Co., 261 U.S. 463, 476 (1923). There Mr. Justice McReynolds declared: "The suggestion that the assailed practice is unfair because of its effect upon the sale of pumps by their makers is sterile and requires no serious discussion." $\mathrm{He}$ also said (at 475) : "The powers of the Commission are limited by the statutes. It has no general authority to compel competitors to a common level, to interfere with ordinary business methods or to prescribe arbitrary standards for those engaged in the conflict for advantage called competition .... it is essential that those who adventure their time, skill and capital should have large freedom of action in the conduct of their own affairs."

155. Federal Trade Commission Act, 38 STAT. 717 (1914), 15 U.S.C. $\$ 41$ (1946).

156. Hautrey, Credit, 4 ENcYc. Soc. Scr. 545, 548 (1931). 
and is thus cutting the price of credit below banker's rates. Theoretically we might prohibit the extension of credit by sellers of other commodities. Concentration of all such transactions in commercial banks might focus lending in a desirable manner. ${ }^{157}$ But the course of trade for centuries indicates that the extension of credit by sellers is a practical necessity. Indeed, there is support for the contention of General Motors ${ }^{158}$ that its extension of credit through GMAC was necessary to effect satisfactory sales. A prominent farm implement company has recently adopted a similar program. ${ }^{150}$

To the extent that price cutting does constitute an attempt to monopolize, it would seem desirable to deal with it under the specific terms of Section 2 of the Sherman Act. ${ }^{160}$ Cutting the price of a particular product with intent to monopolize is surely comparable to the old-fashioned local price cutting upon a geographical basis. Such a territorial discrimination is clearly a violation of the Sherman Act; ${ }^{101}$ Professor Levi has called it a typical "abuse" falling within the prohibitions of that statute. ${ }^{162}$ Neither reliance on other statutes ${ }^{163}$ nor general condemnation of diversification seems necessary.

Price cutting by public utilities. If a business is subject to the fixing of its prices by public authority, diversification (and tying clauses) may have a more serious effect. It is commonplace for fixed price industries to indulge in outside activities. Many public utility companies sell electric or gas appliances and at least one prominent utility company has a large stake in the production of oil. ${ }^{164}$ If such a business is regulated, diversification may become the basis for a scheme to avoid the effect of government control. Vertical integration may

157. Under 62 STAT. 1291 , c. 836,12 U.S.C. $\$ 248 \mathrm{n}$, the Federal Reserve Board was authorized to control consumer credit until June 30,1949 . $\$ 1$ of the Act refers to Exec. Order No. 8843 (1941) which was the basis of the original regulation W. As revised, regulation W, 12 Code Fed. Regs. \$222 (1948) regulated down payments and the interval of subsequent payments in time sales (\$222.3). If all lending transactions were concentrated in commercial banks, it would not be necessary to adopt such elaborate controls over sellers generally. The complaint has been registered that General Motors' easy finance terms sell more automobiles than people "ought" to buy. ARnold, The BotrLenecks of Business 24 (1940).

158. United States v. General Motors Corp., 121 F.2d 376, 406 (7th Cir. 1941). On the other hand, a control of credit may be accomplished better through regulations of the type in question than through an attempt to press the antitrust laws into such prohibitions.

159. International Harvester Company, Ann. Rep., 1948, at 6.

160. 28 STAT. 209 (1890); 15 U.S.C. $\$ 2$ (1946).

161. Standard Oil Co. v. United States, 221 U.S. 1 (1911).

162. Levi, The Antitrust Laws and Monopoly, $14 \mathrm{U}$. of CHr. L. Rev. 153, 158 (1947). But cf. Package Closure Corporation v. Sealright Co., Inc., 141 F.2d 972, 977 (2d Cir. 1944).

163. Cf. $\$ 2$ of the Clayton Act, 38 STAT. 703 (1914); 15 U.S.C. $\$ 13$ (1946).

164. Southern California Edison Company, ANN. ReP., 1948, at 6 (nearly $1 / 4$ th of net profit derived from oil production). Cf. Commonwealth ex rel. Baldridge v. Philadelphia Electric Co., $18 \mathrm{~Pa}$. Corp. Rep. 243 (1929), aff'd, $300 \mathrm{~Pa}$. 577, 151 Atl. 344 (1930) (corporation chartered to supply light, heat and power may properly engage in sale of appliances). 
have a similar effect. Thus it has been charged that a prominent public utility corporation has inflated its rate base by the purchase of supplies and materials from a wholly-owned subsidiary at exorbitant prices. ${ }^{165}$ A good example of the use of diversification to avoid the effect of government control is found in the liquor business under OPA controls. By government action, the price of whiskey was fixed at a low figure in relation to market values. Accordingly, distributors refused to sell whiskey unless rum, gin and other products less in demand were also purchased. The effect of such tying arrangements was to move a considerable quantity of the less desired products at prices above the market with accompanying profit to the dealers, thus enabling them partially to avoid the price control. ${ }^{106}$

More frequently fixed-price businesses are accused of price cutting in the sale of ancillary products. Putting the matter another way, diversification may permit a public utility to juggle its cost figures. Since a utility is guaranteed a limited return upon its public utility business, it may try to allocate the cost of diversified operations to the controlled enterprise and thereby justify rate increases. ${ }^{167}$ It will be noted that the foregoing practice is substantially the reverse of that usually found in the diversification-tying clause situations. There the tied commodity is sold above market price; but erroneous cost accounting will result in the sale of the by-products of the utility below market price. This fact is the source of much complaint from independent dealers who compete with the public utility companies in the sale of electric and gas appliances. They assert that losses incurred in the sale of refrigerators, stoves and the like are recouped by higher rates for utility service. ${ }^{168}$

That the sales of appliances may actually be made below cost is evident from the following statement:

The crux of the matter is whether not a utility shall be priviledged to sell appliances below cost and recoup losses by capitalizing them or by changing them to operating expenses. The public utilities emphasize the promotional aspect, namely, that appliances and service are complementary goods, and that from the standpoint of the consumer, the demand is a joint one. . . . The utilities have urged that the merchandising department is properly a 1949).

165. Complaint in United States v. Western Electric Company, \#17-49 (D.N.J.

166. Coffin-Redington Co. v. Porter, 156 F.2d 113 (9th Cir. 1946) ; N.Y. Times, January 30, 1945, p. 13, col. 6. Cf. Union Pacific Coal Co. v. United States, 173 Fed. 737 (8th Cir. 1909).

167. Barnes, The Economics of Public Utility Regulation 627 (1942).

168. Behling, Competition and Monopoly in Public Utility Industries, 23 IncrNors Studies in the Social Sciences 50 (1938). 
promotional department, and as such should not be required to be self-supporting. The argument that appliance losses are recovered through rates for service is answered by pointing to the decreased costs and lower rates which result from the expansion of business made possible by cheap appliances. . . . ${ }^{169}$

Pressure from independent merchants has resulted in statutes in some states prohibiting the sale of appliances by public utilities. ${ }^{170}$

Considerations of the foregoing character have suggested that public utility companies should be forbidden to diversify. Professor Barnes urged that the utility should be under a heavy burden of proof to justify entry into businesses other than its principal public service. ${ }^{171}$ And Professor Edwards was even more insistent upon a separation of controlled from uncontrolled business. ${ }^{172}$ Perhaps there is no satisfactory basis upon which to fix the prices of public utility concerns. But if regulation is to be attempted it may be necessary to prevent diversification into free markets.

Exclusion from markets. In the pending duPont case ${ }^{173}$ a principal allegation of the complaint is that suppliers are excluded from markets. According to the Attorney General, the duPont Company, General Motors Corporation and the United States Rubber Company enjoy common control by members of the duPont family. That control is so exercised-or a conspiracy among the three corporations has similarly arranged-that the firms trade among themselves whenever possible. General Motors, for example, buys its tires from U. S. Rubber and its paint from duPont. Thus independent tire makers and paint manufacturers are excluded from the General Motors market. ${ }^{174}$

In large measure the question is one of vertical integration. Assuming that the three corporations are under the alleged common con-

169. $I d$. at 51.

170. Id. at 50. Expenditures incurred in such sidelines may be disregarded in fixing rates. People's Gas Co. v. Slattery, 373 Ill. 31, 65, 25 N.E.2d 482, 499 (1940).

171. Note 167 supra, at 277 et seq.

172. Edwards, An Appraisal of the Antitrust Lawe, 36 Proc. Am. Econ. Assn. 172, 262 (1946). In Bonbright and Means, The Holding Conpany 199 (1932) the authors declared: "Whether or not this [Cities Service Company type] interrelation between utility companies and unregulated business companies is desirable from a public point of view is more than doubtful. The greatest danger lies in the menace to the credit of the public utilities when these essential and non-competitive enterprises are financially affliated with highly speculative businesses like oil production."

Several statutes attempt to reach such problems; e.g., Illinois Public Utility Act, I1l. Rev. Stat. c. $1112 / 3$, $\$ \$ 1$ et seq., 12, $27(\mathrm{~g})$ (1947); Civil Aeronautics Act of 1938, 52 STAT. 973 (1938); 49 U.S.C. \$ 401 et seq. (1946). \$ 408 appears to prohibit both control of an air carrier by another type of common carrier and control of an aircraft manufacturer by an air carrier (subject to approval of the CAB).

173. Complaint in United States v. E. I. DuPont deNemours and Co., \#49 C 1071 (1949).

174. Id. complaint fft $20,21,22,24,30$ (b) (1), 30(b) (2). 
trol, they may be regarded as a single, highly diversified firm: there is actually but one enterprise, engaged in many different businesses. To the extent that the different departments of the one concern have occasion to buy supplies from each other, diversification will give rise to the alleged vices of vertical integration. ${ }^{175}$ Thus, it is said, markets may be foreclosed and competition reduced.

In the long run, the alleged exclusion of tire makers other than U. S. Rubber from the General Motors market suggests that General Motors is paying more for its casings than independent suppliers ask. For if the rival rubber firms do not meet U. S. Rubber's price, it is difficult to understand upon what ground it is thought that they should obtain General Motors' business.

But what motive have the duPonts in causing General Motors to pay more than market prices for tires? Can they grow rich by selling to themselves at fancy figures? And if General Motors actually did pay more than market prices for tires, paint and a host of other products, it is difficult to understand how it could compete successfully with rival automobile manufacturers.

In the complaint against the duPonts it is alleged both that U. S. Rubber made unwarranted profits out of its sales to General Motors and that the latter obtained its tires at lower cost than its competitors, thus enhancing its size and power. ${ }^{176}$ It would seem to follow that U. S. Rubber produced tires at lower cost than its competitors. Otherwise the statement would contradict itself. And if U. S. Rubber produced more efficiently, its rivals would stand in a poor position to complain of its success.

Perhaps the foregoing analysis rests upon assumptions of pure and perfect competition. Under conditions of pure competition, "selling costs," which exist in markets characterized by a degree of imperfect competition, would disappear. ${ }^{177}$ The complaint against the duPonts states that General Motors was "giving," and had "arbitrarily granted," a substantial percentage of its business to U. S. Rubber. ${ }^{178}$ Such language implies a market of rigid or sticky prices, possibly made

175. Hale, Vertical Integration, 49 CoL. L. Rev. 921 (1949).

176. Note 173 supra, at II 132, 133. It is alleged in the complaint $(\llbracket 30(\mathrm{c})$ ) that the defendants conspired to prevent diversification by General Motors into the chemical industry. At the same time it is alleged that the defendants agreed to divide the fields of activity among the three corporations (I65). It is difficult to understand how the defendants can be both sued as a combination and also charged with division of territory. If a defendant constituted a single unit in violation of $\S 2$ of the Sherman Act, he could hardly conspire with himself in violation of $\S 1$. Cf. The Sherman Act and the Enforcement of Competition, Discussion, 38 AM. Econ. REv. 204, 206 (1948) (remarks by Mr. Watkins).

177. Chamberlin, The Theory of Monopolistic Conpetition 126 (1938).

178. Note 173 supra, at $\{123$. 
so by reason of the effects of section 2 of the Clayton Act. ${ }^{179}$ Apart from the alleged combination, it suggests the absence of pure competition.

Sales among three companies under common control would reduce selling costs, thus enabling each concern to secure an advantage over its competitors. That advantage would be derived from the elimination of an element of monopoly-conditions of imperfect competition. It is doubtful whether public policy should favor the dissolution of the combination: an attack upon the monopolistic elements in the markets which made the combination profitable might achieve the same immediate results, if any, and also farther reaching benefits.

Control of substitutes. Another complaint against diversification is that it leads to the control of substitutes and hence to monopoly. Since diversification is required to carry a firm into the sale of substitute products, any argument against the control of substitutes may be considered an argument against a form of diversification. Thus it has been said:

A business unit which enters upon the production of a substitute for its original product frequently does so to protect its investment in plant and good will. There is little inducement to such a concern to compete vigorously with itself. ${ }^{180}$

Particular attention has been paid to the entry of newspaper publishers into the field of radio broadcasting. In 1941 the Federal Communications Commission issued an order directing an investigation into applications for broadcasting licenses by persons publishing newspapers. ${ }^{181}$ After much opposition had developed, the Commission finally dismissed the investigation and refused to adopt a general rule on the subject. In doing so, however, it voiced serious doubts as to the desirability of permitting newspaper publishers to operate radio broadcasting stations :

the Commission recognizes the serious problem involved in the broader field of the control of the media of mass communications and the importance of avoiding monopoly of the avenues of communicating fact and opinion to the public. All the Commissioners agree to the general principle that diversification of control of such media is desirable. . . . The Commission does

179. Burling and Sheldon, Price Competition as Affected by the RobinsonPatman Act, 1 WASH. \& LEE L. Rev. 31, 34 (1939); Goodyear Tire \& Rubber Co. v. Federal Trade Commission, 92 F.2d 677 (6th Cir. 1937).

180. Hale, Trust Dissolution, 40 CoL. L. Rev. 615,626 (1940). In that connection it has also been said (supra note 143, at 266): "The protection afforded by competition does not consist merely in the ability to play one trader off against another within a single market. It consists also in the ability to turn to substitute goods and to satisfy one's needs from the products of different industries."

181. 8 F.C.C. REP. 589 (1941). 
not feel that it should deny a license merely because the applicant is engaged or interested in a particular type of business. However, it does not intend in granting licenses in the public interest to permit concentration of control in the hands of the few to the exclusion of the many. . . . ${ }^{182}$

Similar views have been expressed by individual commissioners in cases involving specific applications. Thus Commissioner Fly said that a broadcast license should not be granted when the applicant controlled the only newspaper in the area. ${ }^{183}$

In the realm of public utilities, statutes have specifically prohibited certain types of diversification. Thus the Public Utilities Holding Company Act of 1935 provides that no holding company is to acquire the stock of both electric and gas utilities in the same area when state law prohibitis such action. ${ }^{184}$ A comparable limitation is found in the Communications Act of 1934..$^{185}$

Control of substitutes, except for that achieved by patent control, can result only from diversification. Without the adding of additional commodities to the seller's "line," he can scarcely be said to control substitutes for his basic commodity. On the other hand, it has never been contended that diversification necessarily leads to the control of substitutes. Indeed, the control of substitutes can only occur when diversification is narrowly limited. If diversification extends beyond one "industry," it is unlikely that it will include a "substitute" product. Professor Burns declared that it was difficult to find actual examples of diversification motivated by a desire to control substitutes. ${ }^{188}$

As in the case of tying clauses, control of substitutes depends upon an element of monopoly in the sale of the original product. If a seller of butter enters the oleomargarine business, then, in order to create a wasteful effect, he must either monopolize the butter market or monopolize the oleomargine market. Unless he accomplishes one of the two foregoing results, he will not have caused harm. ${ }^{187}$ Such considerations lead to the conclusion that the mere fact of diversification into the field of substitute products is not a cause of monopoly conditions. Thus Professor Burns said:

182. 9 FED. Reg. 702 (1944) ; Conrad, Economic Aspects of Radio Regulation, 34 VA. I. REv. 283, 291 (1948).

183. Barnes \& Weiland, 8 F.C.C. REP. 46, 54 (1940). Query whether a distinction should be drawn between the problem of substitute control in the field of radio broadcasting and elsewhere in that radio stations broadcast news. (Is monopoly of the dissemination of news worse than other alleged monopolies?)

184. Public Utility Holding Company Act of 1935, 49 Stat. 817 (1935), 15 U.S.C. \& $79 \mathrm{i}(1946)$. 1948).

185. Communications Act of 1934, 48 Stat. 1087 (1934), 47 U.S.C. § 314 (Supp.

186. Note 146 supra, at 454. Professor Burns also declared that substitute integration is not always easy to identify. Id. at 453 .

187. Id. at 455 . 
The opportunity for postponing the introduction of new products or the utilization of new methods depends upon the degree of imperfection of the market. If new substitute products are made but sold at a high price with the object of maintaining the sales of older types, new non-integrated firms with no losses arising from obsolescence may enter the market. Moreover, if the new product is introduced by non-integrated firms, integrated firms whose sales are likely to be reduced may . . . fight for survival by entering the new field of production and may even hasten the decline of prices there. ${ }^{188}$

There are several statutory prohibitions against diversification into substitutes, but these relate chiefly to public utility companies. ${ }^{189}$ Since almost every public utility company enjoys some degree of horizontal monopoly, the statutes may be justified, but any such prohibition upon trade in general might have unfortunate effects. In these times of a rapidly changing economy business may have to run fast in order to stand still. ${ }^{180}$ In other words, it may not be a question of diversification, but of the production of new products to take the place of old ones. Finally, an attempt to prevent diversification into substitute goods would involve serious administrative difficulties. In the last analysis, substitution is a question of degree since almost every service or product competes against every other. It has often been remarked, for example, that consumers have preferred to buy new automobiles rather than to improve their housing conditions. To prevent diversification into substitutes, therefore, might well mean the prevention of diversification altogether.

Continuity of corporate existence. An important effect of diversifcation is that it permits continuity of corporate existence. Even though the product originally made has become obsolete and unsalable, the company may continue as prosperous as before. An interesting example is found in a recent annual report:

188. Id. at 456 .

189. Interstate Commerce Act, 24 STAT. 380 (1887), as amended, 49 U.S.C. $\$ 5$ (1946); New York Public Service Law \& 70. But cf. Stahlman v. Federal Communications Commission, 126 F.2d 124, 127 (D.C. Cir. 1942) wherein it was said: "If in this case it had been made to appear, as counsel for appellant insist, that the Commission's investigation [pursuant to order \#79 of 20 March 1941] was solely for the purpose of the consideration or adoption of a hard and fast rule of policy, as the result of which newspaper owners may be placed in a proscribed class and thus made ineligible to apply for or receive broadcast licenses, we should be obliged to declare that such an investigation would be wholly outside of and beyond any of the powers with which Congress has clothed the Commission. For we have previously held that there is nothing in the Act which either prevents or prejudices the right of a newspaper, as such, to apply for and receive a license to operate a radio broadcast station."

190. Devlin, Making Diversification Pay, Magazine of Wall Street, Nov. 5, 1938, p. 88 , where it is said: "The ability of a company successfully to develop new products and create new markets is the hallmark of corporate vitality and industrial leadership ..." 
Your company was originally started to manufacture husking pins and other hand husking equipment. As time went on the glove and mitten line was added and far outgrew the original products in volume of business. With the improvement of corn husking machines, demand for hand corn huskers dwindled to such small proportions that it was deemed advisable to dispose of this part of our business. ${ }^{191}$

Those who believe in the importance of new firms as promoters of competition ${ }^{192}$ will, of course, find in diversification a cause of monopolistic conditions. They have seen many new fields of industry pre-empted by existing firms. ${ }^{193}$ In other words, diversification prevents a corporation from declining or dying with its product. It perpetuates investments and management powers.

Mere perpetuation of corporate existence does not seem objectionable. While diversification may reduce the number of wholly new firms, the important question is whether that effect is undesirable. A going concern may be in a position to compete more avidly than a newcomer. Certainly the complaint that diversification leads to price cutting suggests such a result. From the standpoint of costs, as suggested above, there may be considerable savings in the diversified, as opposed to the wholly new, enterprise. There is some efficiency in avoiding the closing up and reopening of a business venture. In other words, continuity of operation, however diversified, may in itself result in the saving of costs. But more important, an existing concern has facilities in the nature of purchasing agents, employment officers, accountants and the like, all of whom would have to be recruited anew for a separate venture. Although the new activity undoubtedly increases the costs of maintaining such services, it probably does so at a less than proportional rate.

Avoidance of market appraisal of new ventures. It may be urged that diversification avoids the test of the market place. Funds obtained from corporate earnings and applied to new ventures by-pass the rigorous tests applied by investment bankers to wholly new ventures. If a single man dominates a corporation, his judgment alone may be responsible for entry into a new line of business. No concurrence from the investing public is necessary.

191. The Boss Manufacturing Company, Ann. Rep., 1948, at 2. Another firm said: ". . new products . . . give promise of helping balance the scale for products which have felt the effect of retarded demand." Dow CanmicaI Company, 52ND ANN. REP. at 1 (1949).

192. Oxenfeldt, New Firms and Free Enterprise 17 et seq. (1943).

193. Id. at 45. 
It is true that diversification into new lines may be accomplished without the floating of securities in the investment market. Of course, the question relates as much to horizontal or vertical integration as it does to diversification. And it must be noted that the complaint cannot be made as to capital raised from normal investment sources: at most, the argument relates to the reinvestment of earnings. A clever observer has noted that a company which is in a position to direct its earnings into new facilities would also be favorably situated to attract new capital from investors. ${ }^{194}$ In other words, private investment of earnings in diversified lines is not objectionable because the same result could be reached through the flotation of additional securities.

Retention and reinvestment of earnings does tend to increase total investment. If earnings were all distributed to stockholders in the form of dividends, they would, as indicated above, be heavily penalized by taxation. Again, at least some of the shareholders would use those earnings for current consumption rather than save them for capital purposes. ${ }^{195}$ Thus the whole practice of reinvesting earnings runs into the familiar controversy in regard to "over-saving" and "underinvestment." Although the over-saving theory was once popular, ${ }^{196}$ it is difficult to understand how general standards of living can be raised without additional investment of capital.

Subsidies to ancillary products. A similar argument is that inefficiently made products are subsidized through diversification. A firm may remain profitable despite the fact that one of its products is produced in a wasteful manner. ${ }^{\mathbf{1 9 7}}$ If that is so, it violates one of the canons of competition laid down by Professor Edwards :

Traders must be responsive to incentives of profit and loss; that is, they must not be so large, so diversified, so devoted to political rather than commercial purposes, so subsidized, or otherwise so unconcerned with results in a particular market that their policies are not affected by ordinary commercial incentives arising out of that market. 198

It will be noted that the complaint just mentioned is not wholly different from that of price cutting. In both instances the product is sold below its true cost. In price cutting, however, there is a deliberate effort to injure a competitor.

194. Buchanan, The Economics of Corporate Enterprise 256 (1940). Cf. SweEzy, Socralism 221 et seq. (1949) (attempt to prove that socialist economy will not necessarily result in faulty allocation of resources).

195. BuchaNAN, op. cit. supra note 194, at 257 .

196. Simons, ECONOMIC POLICY For A FreE SOCIETy 185 (1948).

197. THORP AND CROWDER, op. cit. supra note 11, at 666. Cf. note 173 supra, at Iff $30(\mathrm{~b})(4), 30$ (b) (5), 30 (b) (6).

198. Note 143 supra, at 9. 
Diversification does of course raise problems of cost accounting. When diversification is of the divergent type, it will almost certainly give rise to joint costs. Convergent diversification may also give rise to joint costs and even if the products are wholly unrelated, it will still be necessary to allocate certain overhead costs, such as executives' salaries and specialized services, among the several products.

Many methods are used to allocate joint costs. Sometimes the two products are made to bear costs of production in proportion to their weight or bulk. ${ }^{199}$ Upon other occasions, market values of the various commodities are used to allocate joint costs. ${ }^{200}$ It is easy to demonstrate that such methods are arbitrary and can result in fantastic computations. ${ }^{201}$ Professor Viner commonly used an illustration in which a gram of radium was extracted from twenty tons of ore. The radium, of course, was of great value but the slag (by-product) was sold for a pittance. If, however, the allocation of costs were made upon the basis of weight, the result would be the production of radium for almost nothing.

From a theoretical point of view, it is possible to allocate joint costs properly if the entrepreneur is able to vary the output of the several products. ${ }^{202}$ A dispute continues among economists as to whether it is always possible to vary the proportion of the various products produced by joint methods. ${ }^{203}$ Granting that such variation is possible, then familiar marginal principles permit a theoretical allocation of costs. ${ }^{204}$ On the other hand, there is little to indicate that such a computation is practical in an actual business situation. ${ }^{205}$

Similar considerations affect the allocation of overhead costs. Again, several methods of effecting such allocation are used by cost accountants. Only upon marginal principles, however, would it be possible to effect an accurate computation. ${ }^{208}$ And the difficulties involved in any such attempt have led a number of economists to the conclusion that overhead costs cannot be apportioned properly. ${ }^{207}$

199. T.N.E.C. Hearings, Part 17-A, 76th Cong. 2d Sess. 10,092 (1940).

200. T.N.E.C. Hearings, Part 17-A, 76th Cong. 2d Sess. 10,056 (1940). This method also is faulty. Kreps, Joint Costs in the Chemical Industry, 44 QUARTERLY JoURNAL ECON. 416, 420 et seq. (1930).

201. Canning, Cost Accounting, 4 ENCYC. Soc. ScI. 477 (1931).

202. Conference on Price Research, Committee on Price Determination, Cost BeHavior and PrICE Policy 179 (1943). In Kreps, Joint Costs in the Chemical Industry, 44 QUARTERLY J. EcoN. 416, 427 (1930) it is said: "Neither accountants nor economists have been able to devise a method which will yield [joint] cost figures that do not contain a large element of arbitrariness."

203. Conference on Price Researce, supra note 202, at 176 . Kreps, supra note 202 , at 452 .

204. Viner, Cost, 4 ENcYc. Soc. Scr. 466, 473 (1931).

205. CONFERENCE ON PRICE Research, supra note 202, at 177 et seq.

206. Id. at 183, 181 .

207. Garver \& Hansen, Principles of Economics 114 (3d ed. 1947). 
It is thus apparent that diversification may so cloud a concern's cost structure as to result in the shelter of inefficiently made products; a given commodity may be subsidized without the knowledge of its producer. Admitting that such sheltering can occur, it must be noted that the only means of avoiding the cost allocation problems outlined above would be to prohibit all variations in manufacture and distribution. In other words, a manufacturer would be permitted to make only one model, size or style of a commodity. A distributor could vend but a single item. Only then would all common costs be eliminated. While it might not be impossible so to confine manufacturers, it would obviously be inefficient to compel distributors thus to narrow the goods they sell. Such a program would close every department store.

Price rigidity. Diversification is also said to permit the maintenance of prices. Even though demand for a single item is slack and output must be restricted, a diversified producer need not reduce the price of that particular goods. When firms are producing more than one product, the profits from one part of their output may be used to compensate for the losses arising from restriction of other parts of the output. That is, a firm may want to maintain prices for fear of "spoiling" the future market by price reductions. The judgment of the managers might be that, viewed over a long period, the loss should be incurred in the expectation that the situation would be temporary and that future profits would be greater by virtue of their not having "spoiled" the market by price reductions. The restriction may be financed in many ways. Profits from other parts of the output is one possibility. ${ }^{208}$

Price rigidity differs from the sheltering of an inefficiently made product in that it suggests that the commodity is priced too high rather than too low. But it does involve the problems of common costs outlined above. In addition, if a firm diversifies so as to avoid seasonal or cyclical trends, it may thus be enabled to support its price structures. A maker of Christmas tree ornaments who diversifies into the knitting of bathing suits may regularize his receipts in such a manner as to avoid the necessity of reducing the price of his primary product in periods of low seasonal demand. ${ }^{209}$ This is obviously a contradiction of the argument, previously discussed, that diversification leads to price

208. Thorp AND Crowder, op. cit supra note 11, at 668 .

209. Time is an important factor. A merchant does not cut the price of a commodity because a single day's sales are poor. He lets his other goods "carry" the commodity for some period of time. 
cutting. Prices cannot be both too rigid and too fluid at the same time and place. Thus to some degree the argument that diversification leads to price rigidity is balanced by the allegation that it leads to sales below cost. And there is little in available literature to indicate that diversification is an important cause of price rigidity.

Excessive selling costs; increased capital requirements. Again, it is urged that diversification compels competitors likewise to diversify. When one producer starts selling a "full line," all others must do likewise in order to remain in the market. ${ }^{210}$ The effect then may be to increase the amount of capital required to enter the industry. A new enterpriser may find that he is unable to get dealers to handle his new and better product unless he can introduce a complete line and the advertising services to go with it. This increase in capital requirements automatically reduces the number of persons who are able to start new enterprises. ${ }^{211}$ And it is urged that such a raising of capital requirements is inherently wasteful. ${ }^{212}$

The complaint that diversification leads to excessive selling costs is related to the argument against the spreading of trade marks. For the value of a trade mark results from advertising, and vigorous attacks are constantly leveled at merchandising expenditures. ${ }^{213}$ In modern economic thinking sales expenses are suspect. ${ }^{214}$ As to divergent diversification, however, no such argument can be made because the products are not sold together. We may therefore test the thesis that divergent diversification is efficient whereas convergent diversification is wasteful. ${ }^{215}$ The argument would run that the latter type of diversification related only to sales and that selling expenses are uneconomic. On the other hand, it has been said that divergent diversification is not

210. ThORP AND CROWDER, op. cit. supra note 11, at 652 .

211. Raymond, The Limitist 36 (1947). 1938)

212. Chamberlin, The Theory of Monopolistic Competition 123 (3d ed.

2i3. Simons, op. cit. supra note 196, at 71. Cf. Natronal Industrial ConferENCE BoARd, MERGERS AND THE LAW 88 (1929) where it was said: “. . . most manufacturers are constrained to build up their own sales forces and to maintain their own advertising campaigns. This practice has resulted in excessive duplication of selling effort and an enormous waste in advertising outlays. Not infrequently a whole line of similar products may be advertised just as effectively, and with no greater cost, than a single product in the line. The same situation applies to the maintenance of selling agencies, distributing warehouses and like facilities."

214. Chamberlin, op. cit. supra note 212, at 120 et seq. Professor Chamberlin said (at 123): "Cost of production includes all expenses which must be met in order to provide the commodity or service, transport it to the buyer, and put it into his hands ready to satisfy his wants. Cost of selling includes all outlays made in order to secure a demand, or a market, for the product. The former costs create utilities in order that demands may be satisfied; the latter create and shift the demands themselves."

215. Cf. People ex rel. Tiffany \& Co. v. Campbell, 144 N.Y. 166, 38 N.E. 990 (1894) ; Richmond Guano Co. v. Farmer's Ginnery Co., 126 Fed. 712 (4th Cir. 1903) ; Burk v. Mead, 159 Ind. 252, 64 N.E. 880 (1902) (doctrine of ultra vires applied to convergent diversification). 
necessarily efficient. It may cause plant expansion beyond the optimum scale. ${ }^{216}$ Again, convergent diversification may contain elements of efficiency. As we have seen, the practice of "rounding out the line" is indulged in for the benefit of the distributor. Thus a manufacturer practicing convergent diversification may partially replace a wholesaler. ${ }^{217}$ To the extent that he does so, he may be able to function at a reduced cost and thus to increase efficiency. Professor Burns suggested that integration of this type may secure technical economies of production. ${ }^{218}$

In these circumstances it is difficult to arrive at any conclusion regarding the alleged inefficiency of convergent diversification. Perhaps market forces can be counted upon to effect satisfactory adjustments. ${ }^{219}$

\section{Conclusions}

In the larger sense, most of the alleged vices of diversification should be blamed upon the lack of pure ${ }^{220}$ and perfect competition. Diversification is only the surface cause of many economic faults whose roots lie in a degree of horizontal monopoly. Competitive imperfections account for much of the remainder: lack of organized markets, ${ }^{221}$ buyers' inadequate knowledge, absence of standardized commodities and, above all, the factor of time, prevent goods from moving as rapidly and prices as freely as required for maximum utilization of resources. ${ }^{222}$

Coupled with a degree of "horizontal" monopoly, diversification may serve as a basis for undesirable conduct. It may, for instance, supply reserve funds for a price cutting foray. Or it may permit an attempt to monopolize a substitute product, thus adding additional force

216. ThORP AND Crowder, op. cit. supra note 11, at 664 .

217. Id. at 670 .

218. Note 146 supra, at 446. National Industrial Conference Board, supro note 213 , at 89 .

219. One of the outstanding examples of convergent diversification was Standard Brands, Inc. Its delivery service for Fleischmann's Yeast was used as the nucleus of a system of distributing all types of groceries. Recently, however, the company has abandoned the use of its own delivery system. STANDARD BRANDS, INc., ANN. REP., 1948 , at 4. Apparently an oil company has similarly abandoned the sale of sporting goods through filling stations. Phillips Petroleum Co., ANN. Rep., 1948, at 18.

When a trade mark is applied to a new commodity, the question whether its alleged monopoly effect is thereby increased is a difficult one. Professor Burns said in The Deciine of Conipetition (1936), at 447 et seq.: ". . . emphasis upon brand names being an inevitable accompaniment of advertising, attempts to increase the return per unit of advertising expenditure sometimes lead to the use of a brand name for a variety of products. The advertising of each product tends, not only to promote the sales of that product, but also to make the brand name under which it is sold more familiar, and to promote the sales of other products of the same name."

220. Note 212 supra, at 6. (1949).

221. Cf. Hale, Agreements Among Competitors, 33 Mrns. L. REv. 331, 356

222. In United States v. General Motors Corp., 121 F.2d 376, 398 (7th Cir. 1941), cert. denied, 314 U.S. 618 (1941), the court declared that a dealer would suffer a loss if his "franchise" were cancelled. No doubt market imperfections account for such truth as may be contained in that statement. 
to a "horizontal" monopoly power. But this study suggests that diversification is not monopolistic per $s e .{ }^{223}$ The mere fact that a firm produces or distributes more than one commodity should not constitute an infringement of the anti-trust laws. Professor Edwards can almost be taken to have admitted as much. ${ }^{224}$ And even if diversification contained a considerable element of monopoly, its efficiency and stabilizing effect might compel ts to accept it in considerable degree. In addition, the administrative difficulties in its prevention might well prove insuperable. ${ }^{225}$

Horizontal integration is the heart of the monopoly problem: the Sherman Act is the charter of commercial freedom. Efforts to cope with monopoly by attacking "abuses" and "practices" lead to all the contradictions and waste motion of the Clayton Act. They entwine business in a tangle of regulation which can never be fully effective because it does not achieve the reduction of monopoly itself. ${ }^{226}$ If we

223. It is interesting to note that the DuPont Company, officially charged with violation of the Sherman Act, seems to have been less prosperous than two of its less diversified competitors. According to Firch IndrviduAl Stock Bulletins, DuPont profits in 1939 were $\$ 7.66$ per share. In that year Dow Chemical Company earned $\$ .94$ a share and Monsanto Chemical Company $\$ 1.34$ a share. DuPont's 1948 report shows profits of $\$ 13.12$ a share; FrTCH shows Dow's 1948 profit at $\$ 3.72$ a share and Monsanto's 1948 report shows its profit for that year $\$ 3.95$ a share. In other words, DuPont's profits rose $71 \mathrm{I} / 2 \%$ while Dow increased its profits $296 \%$ and Monsanto $195 \%$.

224. Note 143 supra, at 130. Cf. id. at 100.

225. In the General Motors case the company could, so far as extension of credit to dealers alone was concerned, have merely permitted delayed payment on its own books. Certainly there is little authority to suggest that such a practice is unlawful. Again, the question of where protection of good will is justified raises difficult problems. But see United States v. General Motors Corporation, 121 F.2d 376, 407 (7th Cir. 1941) wherein the court says that motive is immaterial.

226. Holmes, J., dissenting in Motion Picture Patent Co. v. Universal Film Mfg. Co., 243 U.S. 502, 519 (1917). Rostow, Monopoly Under the Sherman Act: Power or Purpose? 43 ILL. L. Rev. 745, 772 (1949). But cf. Standard Oil Co. of California v. United States, 337 U.S. 293, 311 (1949). In the Senate Report on the Clayton Act, it was said: "Broadly stated, the bill ... seeks to prohibit . . certain trade practices which, as a rule, singly and in themselves, are not covered by the Act of July 2, $1890 \ldots$ and thus, by making these practices illegal, to arrest the creation of trusts, conspiracies and monopolies in their incipiency . " SEN. REP. \#698, 63d Cong., 2d Sess. (1914). Compare the Wagner Act § 2, $49^{\circ}$ STAT. 449 (1935), 29 U.S.C. § 151 (1947), the avowed purpose of which is to be increase labor's bargaining power, zeith the Norris-LaGuardia Act \& 3, 47 STAт. 70 (1932), 29 U.S.C. \$\$ 101, 103 (1947), prohibiting the enforcement of "yellow dog" contracts. The one enactment directly reduces a citadel of power; the other attempts (obliquely) to control the exercise thereof. Professor Edwards, however, advocates the enforcement of $\$ 3$ of the Clayton Act and even more stringent measures: "In a revised statute the definition of tying arrangements should be extended to include all arrangements that have the effect of binding or inducing any buyer or seller to deal exclusively with another, and likewise all arrangements by which the purchase or sale of one commodity is made conditional upon the purchase or sale of others. It should also cover similar arrangements applicable to agencies and consignment sales. All tying arrangements should be illegal if they are brought about by coercive pressures or if they have the effect of coercing competitors, excluding them from the market, or substantially lessening competition. This blanket prohibition should be supplemented by more specific provisions forbidding tying arrangements applicable to any commodity or service which is subject to a legal monopoly and tying arrangements where either party to the transaction controls a preponderant amount of the total output or of the total sales within a trade area." EDwards, An Appraisal of the Antitrust Lazes, 36 Proc. Axs. Econ. Ass'd 172, 178 (1946). 
should abandon the effort to eliminate monopoly factors on the "horizontal" level it would, of course, be necessary to rely upon the Clayton Act. To preserve a semblance of free market allocation of resources, we should have to bear down on the "abuses." But diversification is not itself an abuse. It is only one of several means of utilizing a monopolistic power. Thus even in a "balanced force" polity diversification need not be condemned as such. The same conclusion would follow if we yield to the importunities of those who would adopt a program of national socialism. A socialist regime, benevolent or otherwise, cannot object to any structure of industry on the grounds that it tends to create a monopoly. For socialism implies (governmental) monopoly.

Diversification may lead to tremendous size without horizontal monopoly. A concern may acquire large resources and remain without undue strength in any one market. This, of course, is the old problem of wealth. Today the crushing burden of taxation can be counted upon rapidly to dissipate the fortunes of natural persons. There remain the corporations, which gather the savings of millions into managed focus. The Supreme Court has said that mere size is not an offense. ${ }^{227}$ But Professors Simons and Edwards argued that a vast concentration of financial power, even in the absence of monopoly, offends the public interest. $^{228}$ In one old decision it was quaintly said:

All experience has shown that large accumulations of property, in hands likely to keep it intact for a long period, are dangerous to the public weal. Having perpetual succession, any kind of a corporation has peculiar facilities for such accumulation, and most governments have found it necessary to exercise great caution in their grants of corporate powers. . . . Freed, as such bodies are, from the sure bound to the schemes of individuals-

227. United States v. United States Steel Corp., 251 U.S. 417, 451 (1920): ". . The Corporation is undoubtedly of impressive size and it takes an effort of resolution not to be affected by it or to exaggerate its influence. "But we must adhere to the law and the law does not make mere size an offense ...."

228. Thus Professor Edwards said: "Bigness gives power whether it is attained in one industry or in many. Great size is common to all giant enterprises whether their strength is based upon monopoly in a single large industry, upon vertical integration, or upon a conglomerate union of activities which are industrially unrelated. The significance of bigness alone is seen most readily in the case of the conglomerate enterprise, in which power, due to size is not reinforced by power due to monopoly or to vertical integration." EDWARDS, MAINTAINING CoMpeTition: ReQUisITES OF A Governmental Policy 100 (1949) ; Simons, Economic Policy for a Free Society 95 (1948).

Professor Simons also said: "Even if the much advertised economies of gigantic financial combinations were real, sound policy would wisely sacrifice these economies to preservation of more economic freedom and equality." Id. at 52. And: "We should look toward a situation in which the size of ownership units in every industry is limited by the minimum size of operating plant requisite to efficient, but highly specialized, production-and even more narrowly limited, if ever necessary to the maintenance of freedom of enterprise." Id. at 60. Cf. Handler, Unfair Competition, 21 IOWA L. REv. 175, 208 (1936). 
the grave-they are able to add field to field and power to power, until they become entirely too strong for that society which is made up of those whose plans are limited by a single life. ${ }^{229}$

Obviously there is a relationship between diversification and size: a tiny concern can scarcely produce many items. Thus Thorp found that the 50 largest corporations in the United States were active in making 2,043 products, that number constituting almost half the number of "products" distinguished in the 1937 Census of Manufacturers. ${ }^{230}$ Three-fourths of the largest concerns made 100 or less products; one made 320 products; and the least diversified made only six..$^{231}$ There is not, however, any necessary correlation between diversification and size since an enterprise can grow large in the production or distribution of a single commodity.

Whether wealth alone is objectionable is a subject beyond the scope of this paper. If it is, what should be done about it is likewise another topic. ${ }^{232}$ All we can now conclude is that diversification as such is not monopolistic.

229. Central R.R. v. Collins, $40 \mathrm{Ga} .582,629$ (1869). Cf. State ex rel. Steubenville Gas Co. v. Taylor, 55 Ohio St. 61, 65, 44 N.E. 513, 515 (1896).

230. ThORP AND Crowder, op. cit. supra note 49, at 586 .

231. Id. at 595 .

232. It may be difficult to determine when objectionable size has been achieved. EDwards, op. cit. supra note 143, at 131 . Perhaps forces of nature will take care of many such situations. Thus Professor Simons said (op. cit. sipra note 228, at 87): "But the ways of competition are devious, and its vengeance-government intervention apart-will generally be adequate and admirable." 